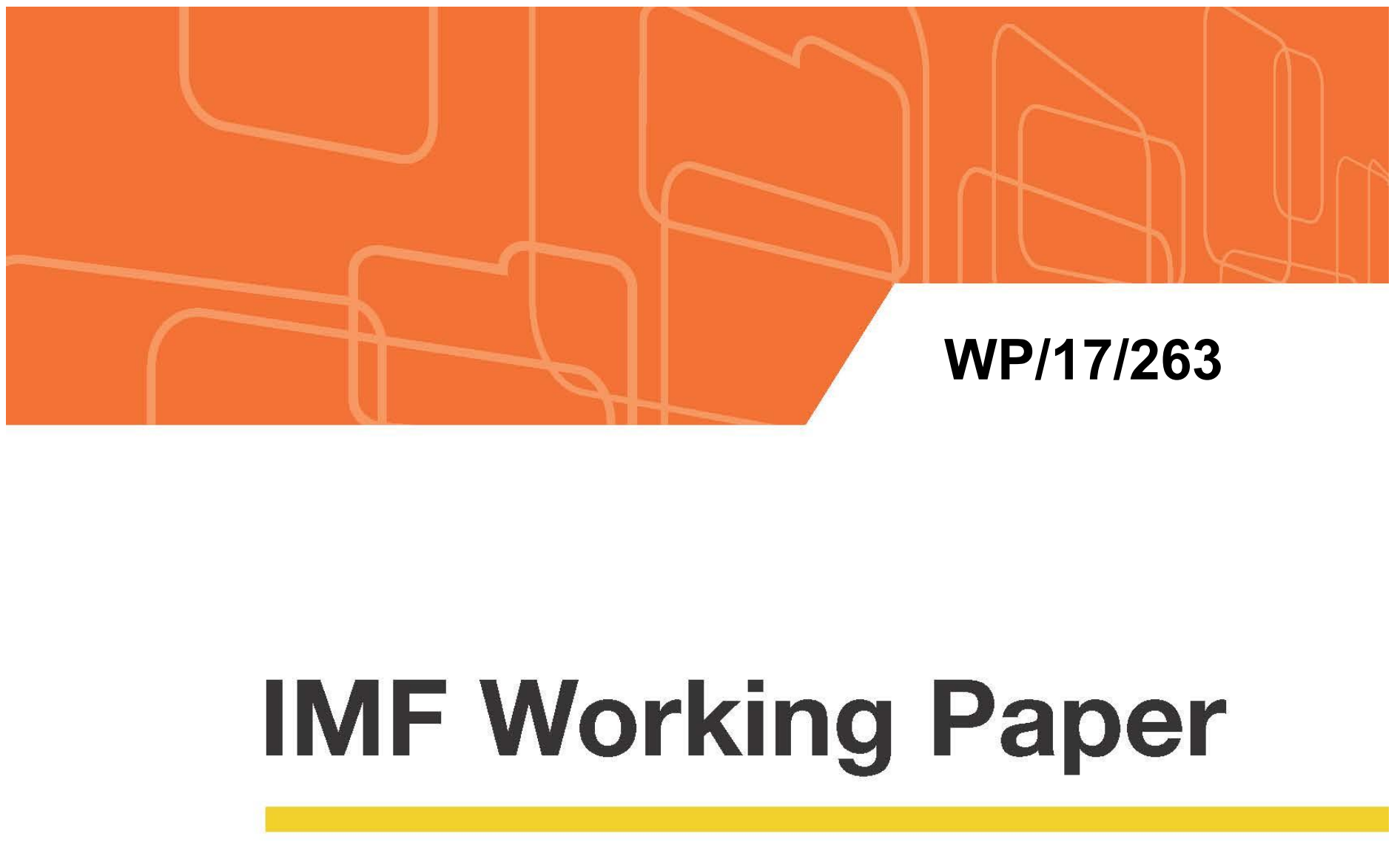

\title{
Currency Mismatches and Vulnerability to Exchange Rate Shocks: Nonfinancial Firms in Colombia
}

\author{
by Adolfo Barajas, Sergio Restrepo, Roberto Steiner, \\ Juan Camilo Medellín, and César Pabón
}

IMF Working Papers describe research in progress by the author(s) and are published to elicit comments and to encourage debate. The views expressed in IMF Working Papers are those of the author(s) and do not necessarily represent the views of the IMF, its Executive Board, or IMF management. 


\title{
IMF Working Paper
}

Institute for Capacity Development

\section{Currency Mismatches and Vulnerability to Exchange Rate Shocks: Nonfinancial Firms in Colombia}

\author{
Prepared by Adolfo Barajas, Sergio Restrepo, Roberto Steiner, \\ Juan Camilo Medellín, and César Pabón ${ }^{1}$
}

Authorized for distribution by Laura Kodres

November 2017

\begin{abstract}
IMF Working Papers describe research in progress by the author(s) and are published to elicit comments and to encourage debate. The views expressed in IMF Working Papers are those of the author(s) and do not necessarily represent the views of the IMF, its Executive Board, or IMF management.
\end{abstract}

\begin{abstract}
After building up foreign currency denominated (FC) liabilities over several years, Colombian firms might be vulnerable to a shift in external conditions. We undertake three empirical exercises to better understand these vulnerabilities. First, we identify the determinants of FC borrowing. Second, we investigate the implications for real activity, finding a balance sheet effect that transmits exchange rate fluctuations to investment and is asymmetric, much stronger for depreciations than for appreciations. Finally, we find that foreign exchange derivatives are not used solely for hedging, due in part to monetary authority intervention to smooth exchange rate volatility. However, a full explanation remains open for future research.
\end{abstract}

JEL Classification Numbers: E22; F31

Keywords: Colombia; depreciation; balance sheet effects; exchange rate derivatives;

Author’s E-Mail Address: abarajas@imf.org, rsteiner@fedesarrollo.org.co, jmedellin@fedesarrollo.org.co, srestran@ banrep.gov.co, cpabon@ fedesarrollo.org.co

\footnotetext{
${ }^{1}$ A. Barajas is at the IMF Institute for Capacity Development. R. Steiner, J.C. Medellín, and C. Pabón are at Fedesarrollo; S. Restrepo is at the External Sector Division at Banco de la República (BdR). The authors thank Luis Brandao Marques, Heedon Kang, Ruy Lama, Julián Caballero, Ugo Panizza, Andrew Powell, Leonardo Villar, Tito Cordella, and César Tamayo, seminar participants at the XX Workshop on Internal Economics and Finance in Buenos Aires, the IDB, and Fedesarrollo. We thank Alberto Boada, Enrique Montes, and Hernando Vargas (all BdR) for providing the database and for their insightful comments and suggestions. An earlier draft was part of the IDB's Latin American and Caribbean Research Network Project "Structure and Composition of Firms' Balance Sheets."
} 


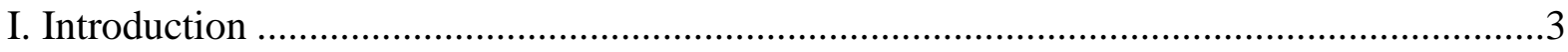

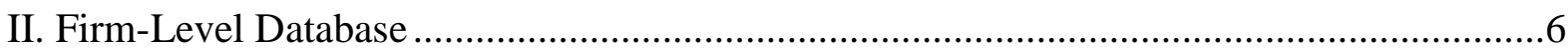

III. The Drivers and Consequences of Holding FC Debt......................................................11

A. Determinants of Issuance of FC Debt ..................................................................11

B. Investment and the Currency Composition of Debt.................................................15

C. Determinants of the Use of Exchange-Rate Derivatives..........................................22

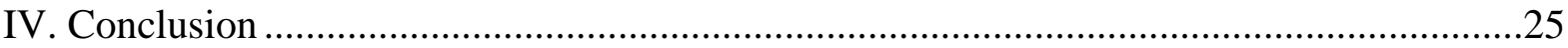

Tables

Table 1. Firms by Sector (Yearly average) .......................................................................

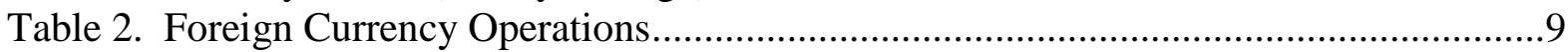

Table 3. Composition of FC Debt (selected years) …….......................................................

Table 4. Descriptive Statistics for Firms Holding Financial Derivatives .................................10

Table 5. Determinants of the Decision to Issue FC Debt (Marginal effects after logit) ..........13

Table 6. Determinants of the Share of FC Debt Issued ..........................................................14

Table 7. Fixed Capital Investment and Foreign Currency Exposure ........................................18

Table 8. Balance Sheet Effect on Investment During a Depreciation Period ............................21

Table 9. Quantile regression: The effect of Balance Sheet Exposure on Investment by

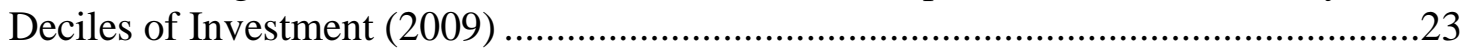

Table 10. Determinants for the Use of Forward Exchange Derivatives by Firms (Marginal effects after logit) 


\section{INTRODUCTION}

In recent years, many emerging markets have benefitted from benign global conditions, including ample liquidity and, until 2013-14, very favorable terms of trade. The enactment of expansionary and often unconventional monetary policies, coupled with very low yields in mature markets, has facilitated access to foreign debt markets by emerging market firms and governments.

In various Latin American countries, bond issuance has also been facilitated by strong macroeconomic fundamentals and/or the upswing in commodity prices. ${ }^{2}$ Colombia has been no stranger to this phenomenon, with private sector debt increasing from around 30 percent of GDP in 2000 to 45 percent of GDP in 2015 (Figure 1). Although more than half of total corporate debt is with domestic financial institutions and two thirds is peso-denominated, since 2009, the share of foreign-currency (FC) debt in total debt has increased markedly, from 20 to 33 percent (Panel A), and the share of credit with foreign financial institutions has gone from 14 to 21 percent (Panel B).

Despite its well-known benefits, the sustained increase in foreign borrowing by nonfinancial firms is also a matter of concern, particularly in a post-2014 global scenario, where monetary conditions have tightened (and are expected to tighten even further) and the collapse in oil prices has left Colombia with the sharpest decline ever in its terms of trade. ${ }^{3}$ The current account deficit went from 3.2 percent of GDP in 2012 to 6.5 percent in 2015 and the peso depreciated by almost 53 percent against the U.S. dollar during that period. The buildup of foreign-currency debt in the context of a volatile and weakening currency is a potential vulnerability, particularly if firms do not match the currency composition of their liabilities with that of their assets, do not use financial derivatives to hedge their exposure to exchangerate risk, or if they do not benefit from a natural hedge in the form of FC revenues.

It is important to highlight that, like in many other emerging economies, Colombia has experienced large swings in international capital flows since the early 1990s. These swings

\footnotetext{
${ }^{2}$ According to Rodriguez, Kamil, and Sutton (2015), gross bond issuance by nonfinancial corporates in LA-5 countries (Brazil, Chile, Colombia, Mexico, and Peru) increased from US\$15 billion in 2003 to US\$77 billion in 2013 (totaling US $\$ 435$ billion over the entire period).
}

\footnotetext{
${ }^{3}$ Between June 2014 and December 2015, the price of Brent crude oil declined by more than 60 percent and the terms of trade did so by more than 40 percent. Even though oil represents only 7 percent of GDP, the macroeconomy is highly sensitive to variations in the price of hydrocarbons. In 2014, oil exports accounted for 53 percent of total exports, while foreign direct investment (FDI) in the hydrocarbons sector represented 30 percent of total FDI. Regarding fiscal dependence on oil, taxes from oil companies and profits from the state-controlled oil company accounted for 20 percent of central government current revenue in 2014.
} 
Figure 1. Corporate Debt

Panel A. By currency denomination (\% of GDP)

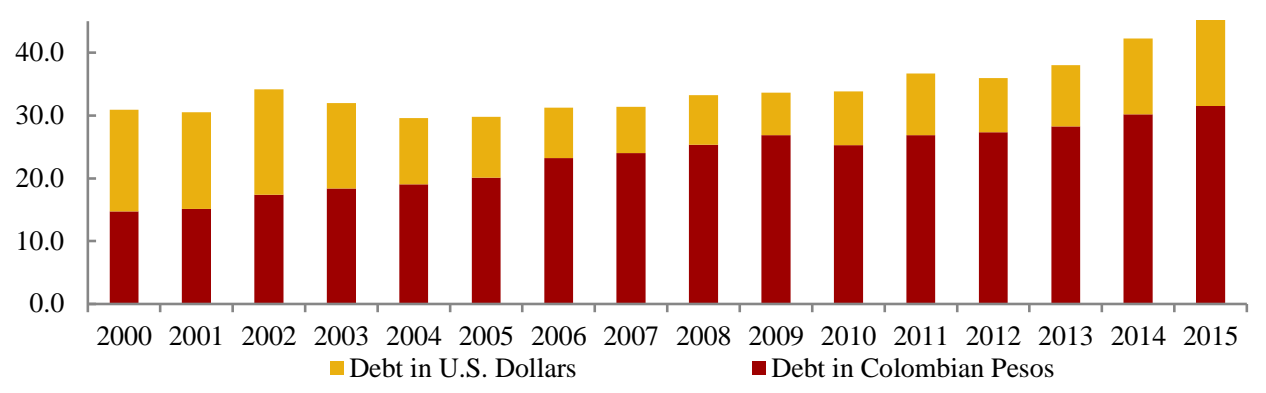

Panel B. By source (\% of GDP)

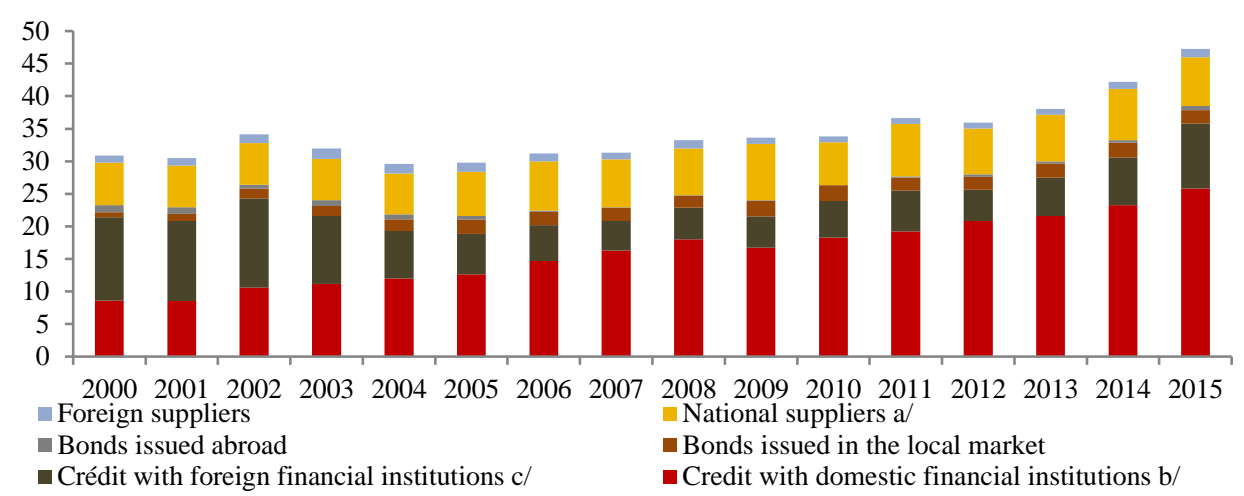

Source: Central Bank, based on data from the Societies Superintendence of Colombia.

Note: Because of data limitations, the 2015 trade credit is assumed equal to the one observed in 2014.

have generally been associated with similar swings in economic activity working through two channels: exchange rate changes and bank credit. Regarding exchange rates, the resulting real appreciation during the upswing has contributed to a shift in economic activity toward the nontradable sector (Cano, 2010).

The relevance of a balance sheet channel transmitting exchange rate fluctuations to the real economy is now well established in the literature. Since the work of Krugman (1999) and Céspedes, Chang, and Velasco (2002), among others, it has been recognized that-if currency mismatches are large enough - the traditional beneficial impact of currency depreciations might be overturned, as firms with large currency mismatches - a net liability exposureexperience distress due to a weaker local currency. ${ }^{4}$ Braggion, Christiano, and Roldós (2007)

\footnotetext{
${ }^{4}$ However, Céspedes et al. (2002) also show that for plausible parameters, the traditional positive growth effects of exchange rate depreciation, while weakened, might still dominate. Similarly, Gertler, Gilchrist, and the Natalucci
}

(continued...) 
then argue that, in the presence of financial frictions, the optimal policy to confront a sudden stop in capital flows - such as that encountered in the Asian Crisis - is to raise interest rates sharply in the short term, thereby counteracting the initial depreciation of the local currency. Over time, as financial frictions ameliorate, the policy may be reversed, lowering interest rates to below pre-crisis levels.

In the case of Colombia, one strand of related empirical work has focused on factors that contribute to the buildup of liabilities in foreign currency and on firm-level balance sheet effects that ensue from sizable depreciations. ${ }^{5}$ Echeverry et al. (2003) found that vulnerabilities were relatively limited during 1995-2001, mainly because the buildup of FC liabilities was modest and mostly limited to "naturally hedged" firms (i.e., those with a sizable portion of revenues in foreign currency). They also showed that, amidst a real exchange-rate depreciation, firms with FC debt generally had lower profitability but similar levels of investment than other firms. Restrepo, Cuervo, and Montes (2014) found that substantial currency mismatches have been arising more recently, as firms in Colombia do not match the currency composition of their liabilities with those of their assets and income.

With global monetary conditions now beginning to tighten ${ }^{6}$ and expected to tighten further, compounded with a collapse Colombia's terms of trade in recent years, the accumulated foreign borrowing by non-financial firms is a matter of concern. At the extreme, a sharp depreciation could bankrupt firms with large currency mismatches, with severe consequences for the real economy as well for other creditors and even government finances. However, a less extreme outcome is also troublesome; the possibility that vulnerable firms may need to cut back on investment as they respond to an adverse shock to their balance sheets. It is therefore relevant to assess to what extent vulnerabilities - balance sheet mismatches that are insufficiently hedged, either naturally or financially — may have built up over the past few years.

(2007) analysis of the Korean 1997-98 financial crisis, illustrate how the pre-crisis commitment to a fixed exchange rate exacerbated output and productivity losses.

${ }^{5}$ For 32 developed and developing countries, Calvo, Izquierdo, and Mejía (2004) found that the interaction of large current account deficits and high dollarization may be a dangerous cocktail, as potential balance sheet effects become highly relevant in determining the probability of a Sudden Stop. For six Latin American countries, Kamil (2012) showed that fixed exchange rates may play a role in building up these vulnerabilities.

${ }^{6}$ Evidence found in the gradual shift in the monetary policy stance of the Federal Reserve System of the United States. After seven years of near-zero rates, in December of 2015, the Federal Open Market Committee began a cycle of successive increases in the target range of the federal funds rate, first from $0.0-0.25$ to $0.25-0.5$ percent and eventually to $1.0-1.25$ percent on June 14, 2017. 
The purpose of this paper is first to econometrically identify the determinants of foreign borrowing by nonfinancial corporations and then to assess the vulnerability of the real economy by estimating the effect of such borrowing on firm performance and investment behavior.

We provide evidence through probit/logit estimations that larger, more leveraged, foreignowned firms are more likely to acquire FC debt. Secondly, we find evidence of a balance sheet effect transmitting exchange rate fluctuations to real investment. Although statistically significant, the magnitude of the balance sheet effect estimated over the entire 2005-13 sample period was relatively small, thus suggesting asymmetry in the sensitivity to depreciations versus appreciations. This was confirmed by our event study, in which we found a substantially larger effect surrounding 2009, the one year when a substantial real depreciation occurred. We also studied the factors behind nonfinancial firms' decision to participate in the FC forward market. Although we are aware that the frequency of our data imposes some limitations to completely capture the complexities of the FC forwards market, our exercises point out that not all firms use forward exchange derivatives solely to hedge their FC liabilities. Our hypothesis, and a question that remains open for future research, is that the Colombian monetary authority's exchange rate intervention to reduce exchange rate volatility also reduces incentives for hedging among some agents in the market.

The paper is divided into four sections, including this introduction. In the second section, we describe the database. In the third section, we motivate and undertake the econometric exercises. In the last section, we conclude.

\section{Firm-LeVel DATABase}

We use balance sheet and income statements for nonfinancial firms for the 2005-13 period, as provided by the Colombian Societies Superintendency (SS) and the Financial Superintendency of Colombia (SFCC). ${ }^{7}$ These standardized data sets cover firms with assets or annual revenue in excess of 30,000 times the monthly minimum wage. ${ }^{8}$ The total number of observations is 215,016 , with a yearly average of 23,890 firms ranging between 19,744 and 27,091. As reported in Table 1, retail and manufacturing comprise the largest number of firms in the database. For the currency composition of assets and liabilities, firm-level FDI, and the use of

\footnotetext{
${ }^{7}$ Even though SS information is available as of 1995, we consider only information since 2005 to ensure that we work with high-quality data. Other variables, including financial derivatives, are only available for this shorter period. Note that our sample includes both state-owned and privately-owned firms.

${ }^{8}$ In 2015 the monthly minimum wage was US\$235. Hence, only firms with assets above US\$7 million were subject to mandatory reporting.
} 
financial derivatives, we use data from Banco de la República (BdR). Imports (CIF) and exports (FOB) come from DANE-DIAN. ${ }^{9}$ The definition and sources of all variables are reported in Annex A.

Since they are more likely to borrow in FC, larger firms tend to have greater balance sheet FC mismatches and are more likely to have either a natural or a financial hedge. Thus, they are of interest for this paper. Our sample also includes a substantial number of large firms that do not have foreign-currency denominated debt, which will allow us to understand both the determinants of holding FC debt and the impact of exchange rate changes on investment. We apply the following filters to the original database:

1. We first remove observations with faulty data; that is, firms in which either of the following ratios are less than 0.01 or greater than 1.1 :

- $\quad$ FC debt (bonds, credit from financial institutions and trade credit) to total debt;

- $\quad$ FC assets to total assets; and

- $\quad$ Export revenues to operational income.

2. Having applied the above filters, in each year we rank all remaining firms by asset size and maintain only those above the $75^{\text {th }}$ percentile. ${ }^{10}$

3. We then attempt to balance the panel as much as possible by removing firms that do not have at least 5 years of data.

The resulting working sample contains 38,523 observations with a yearly average of 4,280 firms, ranging between 3,479 and 4,847 (Table 1). The descriptive statistics and the econometric exercises that follow refer to these 4,280 firms. ${ }^{11}$

For all firms in our sample, ${ }^{12}$ Panel A of Table 2 reports totals (in USD millions) for FC debt $^{13}$,

${ }^{9}$ DANE is the acronym for Colombian National Administrative Department of Statistics. DIAN is the acronym for the Colombian National Tax and Customs Administration.

${ }^{10}$ As our database is composed mostly of small firms that do not have FC debt, FC assets, exports, or imports, we decided to work with the upper $25^{\text {th }}$ percentile. This left us with a reasonably large number of heterogeneous firms.

${ }^{11}$ Except for the second econometric exercise in Section 3.1, where we only consider firms holding FC debt.

${ }^{12}$ Annex B reports some descriptive statistics (averages for 2005-13) for our sample of firms.

${ }^{13}$ Note that our definition of FC debt includes only debt denominated in foreign currency, excluding debt issued abroad in domestic currency. The latter is relevant in the case of some state-owned firms.

(continued...) 
FC assets, net forwards, and net exports (exports minus imports of goods and services). FC assets are relatively small compared to debt. The net forward position-i.e., the difference between long and short positions in currency forwards ${ }^{14}$ - is negative for the sample period, implying that, on the aggregate, firms took a short position, not hedging FC debt. Additionally, net exports are highly positive for 2009 and 2013. In Panel B, we report averages per firm as a percentage of total assets. ${ }^{15}$ Column (4) shows the averages for our main variable of interest in the econometric exercises of Section 3.2: Balance-Sheet Exposure (FC debt minus FC assets minus Net Forwards).

\section{Table 1. Firms by Sector}

(Yearly average)

\begin{tabular}{lrr}
\hline & $\begin{array}{c}\text { Original } \\
\text { database }\end{array}$ & $\begin{array}{c}\text { Our } \\
\text { sample }\end{array}$ \\
\hline Agriculture & 1,553 & 319 \\
Retail & 13,866 & 2,116 \\
Construction & 2,386 & 389 \\
Electricity, gas and water & 78 & 17 \\
Manufacturing & 4,483 & 1,208 \\
Oil and Mining & 498 & 117 \\
Transport and communication & 906 & 114 \\
Total & $\mathbf{2 3 , 7 7 0}$ & $\mathbf{4 , 2 8 0}$ \\
\hline
\end{tabular}

Source: Authors calculations based on SS, DIAN-DANE, SFCC and BdR.

As we delve into the components of firm's FC debt, we find that the largest share corresponds to FC loans (representing between 70 percent and 90 percent of the total). It is worth noting that FC bonds ${ }^{16}$ more than doubled their share between 2005 and 2013 despite there being only nine $^{17}$ issuers in our sample (Table 3; Panel A). Furthermore, when we scale by total assets, we

\footnotetext{
${ }^{14}$ The forward contract is the net position of active contracts as of December 31, of each year for each firm. Although the raw data base has a daily frequency, we take the net position as of the end of each year, which is the frequency of the other variables in our database. In general, the average duration of a COP/USD forward contract ranges between 1-3 months and is traded between nonfinancial firms and banks. Although forward contracts are not the only FC derivatives available, they account for 95 percent of the value of operations and for 99 percent of the number of derivatives operations.

${ }^{15}$ Net exports are positive when added across firms but negative for the average firm. This is because one firm, Ecopetrol - the national oil company — accounts for a huge share of all exports.

${ }^{16}$ All FC bonds were issued in foreign markets.

${ }^{17}$ Nine different firms issued bonds during the period of study, and the maximum number of bond issuers in a given year was four.
} 


\section{Table 2. Foreign Currency Operations}

Panel A. Balance-Sheet Exposure (in USD millions)

\begin{tabular}{ccccccc}
\hline Year & \# Firms & $\begin{array}{c}\text { FC debt } \\
\mathbf{( 1 )}\end{array}$ & $\begin{array}{c}\text { FC assets } \\
\mathbf{( 2 )}\end{array}$ & $\begin{array}{c}\text { Net Fwds } \\
\mathbf{( 3 )}\end{array}$ & $\begin{array}{c}\text { Balance- } \\
\text { sheet } \\
\text { exposure } \\
(\mathbf{4})=(\mathbf{1})-(\mathbf{2})-\end{array}$ & $\begin{array}{c}\text { Net } \\
\text { exports } \\
\mathbf{( 5 )}\end{array}$ \\
\hline 2005 & 3479 & 5410 & 681 & -766 & 5496 & -1018 \\
2009 & 4847 & 9690 & 682 & -601 & 9609 & 937 \\
2013 & 4031 & 17328 & 2939 & -1497 & 15886 & 7238 \\
\hline
\end{tabular}

Panel B. Balance-Sheet Exposure per Firm (ratios to total assets, except for FC debt/total debt)

\begin{tabular}{cccccccc}
\hline Year & \# Firms & $\begin{array}{c}\text { FC debt } \\
(\mathbf{1})\end{array}$ & $\begin{array}{c}\text { FC } \\
\text { assets } \\
\mathbf{( 2 )}\end{array}$ & $\begin{array}{c}\text { Net } \\
\text { Fwds (3) }\end{array}$ & $\begin{array}{c}\text { Balance- } \\
\text { sheet } \\
\text { exposure } \\
(\mathbf{4})=(\mathbf{1})- \\
(\mathbf{2})-(\mathbf{3})\end{array}$ & $\begin{array}{c}\text { Net } \\
\text { exports } \\
\mathbf{( 5 )}\end{array}$ & $\begin{array}{c}\text { FC debt } \\
\text { / Total } \\
\text { debt }\end{array}$ \\
\hline 2005 & 3479 & $3.0 \%$ & $0.6 \%$ & $-0.6 \%$ & $2.9 \%$ & $-4.1 \%$ & $5.5 \%$ \\
2009 & 4847 & $2.4 \%$ & $0.4 \%$ & $-0.3 \%$ & $2.3 \%$ & $-4.4 \%$ & $4.3 \%$ \\
2013 & 4031 & $3.1 \%$ & $0.6 \%$ & $-0.5 \%$ & $3.0 \%$ & $-7.9 \%$ & $5.5 \%$ \\
\hline
\end{tabular}

Source: Authors calculations based on SS, DIAN-DANE, SFC and BdR.

Table 3. Composition of FC Debt (selected years)

Panel A. In USD millions

\begin{tabular}{cccccccc}
\hline Year & \# Firms & $\begin{array}{c}\text { \# Bond } \\
\text { issuers per } \\
\text { year }\end{array}$ & $\begin{array}{c}\text { Bonds } \\
(\mathbf{1})\end{array}$ & $\begin{array}{c}\text { Loans } \\
\mathbf{( 2 )}\end{array}$ & $\begin{array}{c}\text { Financial debt } \\
(\mathbf{3})=(\mathbf{1})+(\mathbf{2})\end{array}$ & $\begin{array}{c}\text { Trade } \\
\text { Credit }\end{array}$ & $\begin{array}{c}\text { FC } \\
\mathbf{d e b t} \\
\mathbf{( 4 )}\end{array}$ \\
\hline 2005 & 3479 & 4 & 717 & 4,359 & 5,076 & 335 & 5,410 \\
2009 & 4847 & 4 & 1,482 & 7,612 & 9,094 & 596 & 9,690 \\
2013 & 4031 & 3 & 4,939 & 12,224 & 17,163 & 165 & 17,328 \\
\hline
\end{tabular}

Panel B. Average Value per Firm (as a percentage of total assets)

\begin{tabular}{cccccccc}
\hline Year & \# Firms & $\begin{array}{c}\text { \# Bond } \\
\text { issuers }\end{array}$ & Bonds (1) & Loans (2) & $\begin{array}{c}\text { Financial } \\
\text { debt } \\
(\mathbf{3})=(\mathbf{1})+(\mathbf{2})\end{array}$ & $\begin{array}{c}\text { Trade } \\
\text { credit (4) }\end{array}$ & $\begin{array}{c}\text { FC debt } \\
(\mathbf{5})\end{array}$ \\
\hline 2005 & 3479 & 4 & $0.03 \%$ & $2.5 \%$ & $2.5 \%$ & $0.5 \%$ & $3.0 \%$ \\
2009 & 4847 & 4 & $0.01 \%$ & $1.8 \%$ & $1.8 \%$ & $0.6 \%$ & $2.4 \%$ \\
2013 & 4031 & 3 & $0.01 \%$ & $2.9 \%$ & $2.9 \%$ & $0.1 \%$ & $3.1 \%$ \\
\hline
\end{tabular}

Source: Authors calculations based on data from SS, DIAN-DANE, SFC. and BdR. 
can see that FC debt decreased in the first years of the sample from 3 percent to 2.4 percent, but increased after 2009, reaching 3.1 percent (Panel B).

Table 4 focuses on a sub-sample of firms that held any amount of an FC forward at the end of each year. Manufacturing, agriculture, and retail are the sectors most heavily represented in this group. Panel A shows that in all sectors, except for construction, a very high percentage of firms using FC forwards are involved in international trade. The percentage of firms that hold financial derivatives and carry FC debt, although high, is substantially lower. In panel B, holdings of financial derivatives are disaggregated between long and short forward positions. Most sectors have a larger short than long forward position.

It is important to highlight that firms in agriculture exhibit the largest long forward positions (2.2 percent of total assets) as well as the largest net forwards as a share of total debt (4.8 percent). With the exception of agriculture, transportation, and communications, firms have short net positions - i.e., they were net sellers of foreign currency. As expected, the sectors involved in foreign trade are the most active in the FC derivatives and FC debt markets. Nevertheless, there is no clear evidence of why firms use FC derivatives. While agricultural

\section{Table 4. Descriptive Statistics for Firms Holding Financial Derivatives}

\begin{tabular}{|c|c|c|c|}
\hline \multicolumn{4}{|c|}{ Firms descriptive statistics by industry } \\
\hline & $\begin{array}{l}\% \text { of firms } \\
\text { with Fwds }\end{array}$ & $\begin{array}{l}\% \text { of firms with Fwds and } \\
\text { international trade }\end{array}$ & $\begin{array}{c}\% \text { of firms with } \\
\text { Fwds and FC debt }\end{array}$ \\
\hline Agriculture & 11.5 & 10.0 & 6.7 \\
\hline Retail & 9.6 & 8.1 & 6.7 \\
\hline Construction & 3.1 & 2.2 & 2.5 \\
\hline Electricity, gas and water & 7.7 & 7.7 & 3.9 \\
\hline Manufacturing & 16.9 & 16.7 & 13.7 \\
\hline Oil \& Mining & 3.9 & 3.5 & 3.0 \\
\hline Transport and communications & 5.9 & 5.1 & 4.1 \\
\hline
\end{tabular}

Panel B. Long, short and net forwards positions (as a ratio of total assets; average 2005-2013)

Firms descriptive statistics by industry

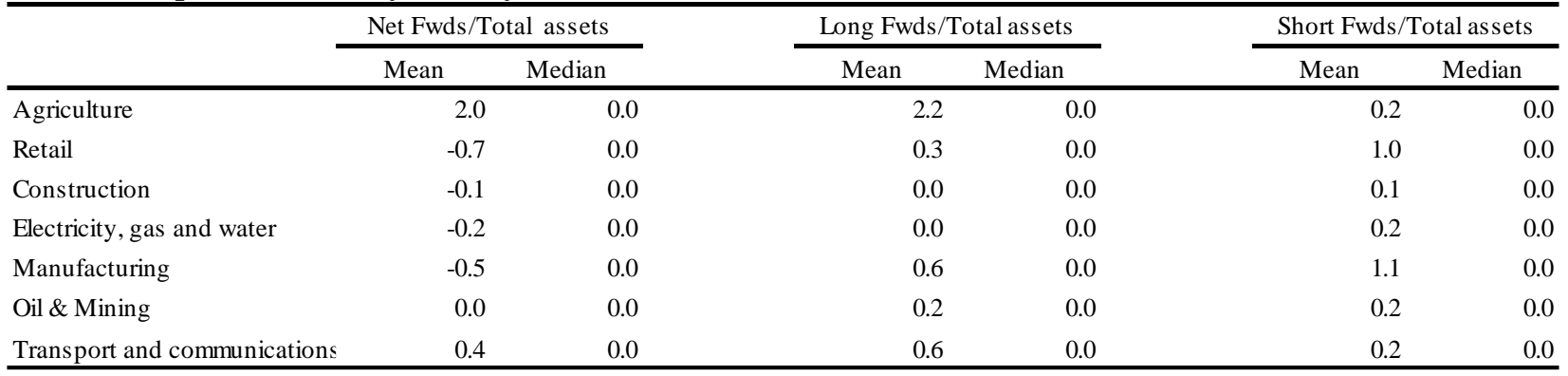

Source: Authors calculations based on SS, DIAN-DANE, SFC and BdR. 
firms might be using them to hedge their FC liabilities, manufacturing and retail firms possess both short and long positions, with the short position being much larger, thus suggesting speculative rather than hedging behavior.

\section{The DRIVERS AND CONSEQUenCES OF HoLding FC DEBT}

In this section, we address three questions referring to nonfinancial firms: (i) which factors drive the decision to issue FC debt, and in what quantities? (ii) what is the impact on firm performance (i.e., investment) of holding FC debt in the presence of exchange rate fluctuations? and (iii) what are the determinants of the use of exchange rate derivatives (FC forwards)?

\section{A. Determinants of Issuance of FC Debt}

To assess the importance of the different factors that might affect a firm's decision to issue FC debt, we follow Echeverry et al. (2003), as follows:

$$
\begin{gathered}
F C_{i, t}=\propto_{i}+\beta_{1} A_{i, t}+\beta_{2} L_{i, t}+\beta_{3} Z_{i, t}+\beta_{4} F O_{i, t}+\beta_{5} G_{i, t} \\
+\beta_{6} I_{i, t}+\beta_{7} S_{i, t}+\beta_{8} I P_{i, t}+\rho_{1} s_{t}+\rho_{2} c_{t}+e_{i, t}
\end{gathered}
$$

$\mathrm{FC}$ is a dummy variable equal to 1 for the year $t$ in which firm $i$ acquired (any amount of) FC debt, 0 otherwise. The firm-level explanatory variables are: $A$, the logarithm of total assets; $L$, leverage, the ratio of total liabilities to total assets; $Z$, exports in relation to total sales; $F O$, a dummy variable equal to 1 if 50 percent or more of the firm's equity is owned by foreigners; $G$, the rate of growth of sales; $I$, FC assets held abroad ${ }^{18} ; S$, the ratio of short-term debt to total debt; and $I P$, imports as a ratio of total operational expenses. We have included two macroeconomic variables: $s$, the difference between the domestic interbank interest rate and overnight LIBOR minus the premium on exchange-rate forward contracts, to capture the cost differential between domestic and foreign borrowing; and $c$, domestic credit to the private sector as a percentage of GDP. We also estimate a slightly different specification in which macroeconomic variables are replaced with time effects.

We run three different versions of (1), all of them as a logit regression. ${ }^{1 / 20}$ In the first, the dependent variable includes all three types of FC liabilities (bonds, bank loans, and trade

\footnotetext{
${ }^{18}$ FC denominated assets held within the country are not known.

${ }^{19}$ When a probit model is used for the Total FC Debt and Financial FC debt estimations, results are robust to the econometric methodology, coefficients signs and significance remain similar. However, there are no firm-level determinants when the FC trade credit is used as the dependent variable in a probit model. See Annex C.

${ }^{20}$ We preferred a RE model, since under FE we could only include firms that had changed their issuing behavior during the period of study, and therefore the sample size was reduced by two-thirds. In Annex E we include the
}

(continued...) 
credit). In the second, it only includes financial debt (bonds and bank loans). The third only includes trade credit. Results are very similar for the three exercises.

As can be seen in Table 5, most variables have the expected sign and are significant at the 10 percent confidence level. The probability of issuing any kind of FC debt increases with size, leverage, and with the ratio of exports to total sales. The significance of the exports to total sales variable may be indicative of "natural hedging;" that is, firms that are naturally hedged are in a better position to issue FC liabilities. The probability of issuing any kind of FC debt declines with the rate of growth of sales, an indication that the ability of the firm to self-finance its investment needs increases with sales, as shown in Rajan and Zingales (1998). Firms that rely more on short-term debt, are importers, or are foreign-owned, are more likely to issue FC debt. Regarding macroeconomic variables, the probability of issuing any kind of FC debt increases when there is an increase in the spread (the interest rate differential adjusted by the forward premium). Total and financial FC debt does not appear to substitute for domestic bank credit. Issuance is actually more likely when aggregate credit to the private sector is on the upswing; thus, FC debt issuance is pro-cyclical with respect to domestic credit conditions. Finally, trade credit behaves somewhat differently, decreasing when domestic credit conditions loosen.

Having specified regression (1) to determine the decision of whether to issue FC debt, we now limit the sample to issuing firms to understand what drives the amount of FC debt issued, as proxied by the ratio of FC denominated debt to total assets $(F C S)$.

$$
\begin{gathered}
F C S_{i, t}=X_{i, t} B+a_{i}+\rho_{1} s_{t}+\rho_{2} c_{t} \\
+s_{t}\left[\beta_{1} A_{i, t}+\beta_{2} Z_{i, t}+\beta_{3} F O_{i, t}+\beta_{4} I P_{i, t}\right] \\
+c_{t}\left[\delta_{1} A_{i, t}+\delta_{2} Z_{i, t}+\delta_{3} F O_{i, t}+\delta_{4} I P_{i, t}\right]+e_{i, t} \\
\text { where } \mathrm{X}=[\mathrm{A}, \mathrm{L}, \mathrm{Z}, \mathrm{FO}, \mathrm{G}, \mathrm{I}, \mathrm{S}, \mathrm{IP}]
\end{gathered}
$$

The dependent variable $F C S$ is now continuous, but explanatory variables are as in (1) above. Also, we include interactions between the macro variables with exports in two additional specifications: the foreign ownership dummy variable and imports. As in the previous exercise,

fixed effects results, where the size of the firm is the only FC debt driver that is significant (and positive) for five different specifications, while leverage is positive and significant for three different specifications. A Hausman test on all six specifications yielded inconclusive results (Annex D). From (1) to (4) the test suggests a fixedeffects (FE) model, for (5) the data fails to meet the asymptotic assumptions of the test and for (6) the test suggests a random effects (RE) model.

We also provide results running the model as pooled data, that is, with no firm-specific intercepts. In Annex F, Panel A, logit results are exhibited; in Panel B, probit results are given. Most results hold in comparison to the random effects model. The only differences that stand out in both logit and probit regressions are that i) imports are positive and significant throughout the six specifications, and that ii) the spread variable is no longer significant. 
we run different versions of (2), using three definitions of (the amount of) FC debt as the dependent variable. We run Equation (2) as a fixed-effects panel regression.

Table 5. Determinants of the Decision to Issue FC Debt (Marginal effects after logit)

\begin{tabular}{|c|c|c|c|c|c|c|}
\hline VARIABLES & $\begin{array}{c}(1) \\
\text { Logit } \\
\text { Total FC Debt }\end{array}$ & $\begin{array}{c}(2) \\
\text { Logit } \\
\text { Financial FC Debt }\end{array}$ & $\begin{array}{c}(3) \\
\text { Logit } \\
\text { FC Trade Credit }\end{array}$ & $\begin{array}{c}(4) \\
\text { Logit } \\
\text { Total FC Debt }\end{array}$ & $\begin{array}{c}\text { (5) } \\
\text { Logit } \\
\text { Financial FC Debt }\end{array}$ & $\begin{array}{c}\text { (6) } \\
\text { Logit } \\
\text { FC Trade Credit }\end{array}$ \\
\hline A, Assets & $\begin{array}{l}0.0512 * * * \\
(0.00452)\end{array}$ & $\begin{array}{l}0.0338 * * * \\
(0.00296)\end{array}$ & $\begin{array}{c}0.000120 * * * \\
(2.66 \mathrm{e}-05)\end{array}$ & $\begin{array}{l}0.0518 * * * \\
(0.00453)\end{array}$ & $\begin{array}{l}0.0341 * * * \\
(0.00297)\end{array}$ & $\begin{array}{l}0.000101 * * * \\
(2.35 \mathrm{e}-05)\end{array}$ \\
\hline $\begin{array}{c}\text { I, Assets held } \\
\text { abroad }\end{array}$ & -0.00959 & -0.0123 & 0.000399 & -0.0128 & -0.0133 & 0.000387 \\
\hline & $(0.0537)$ & $(0.0318)$ & $(0.000574)$ & $(0.0571)$ & $(0.0342)$ & $(0.000511)$ \\
\hline $\mathrm{L}$, Leverage & $\begin{array}{l}0.289 * * * \\
(0.0389)\end{array}$ & $\begin{array}{l}0.175 * * * \\
(0.0241)\end{array}$ & $\begin{array}{c}0.000763 * * * \\
(0.000210)\end{array}$ & $\begin{array}{l}0.291 * * * \\
(0.0389)\end{array}$ & $\begin{array}{l}0.177 * * * \\
(0.0242)\end{array}$ & $\begin{array}{c}0.000649 * * * \\
(0.000186)\end{array}$ \\
\hline $\mathrm{S}$, Short term debt & $\begin{array}{c}0.0585^{* * * *} \\
(0.0119)\end{array}$ & $\begin{array}{c}0.0393 * * * \\
(0.00757)\end{array}$ & $\begin{array}{l}0.000132 * \\
(7.87 \mathrm{e}-05)\end{array}$ & $\begin{array}{c}0.0564 * * * \\
(0.0119)\end{array}$ & $\begin{array}{c}0.0389 * * * \\
(0.00758)\end{array}$ & $\begin{array}{c}7.76 \mathrm{e}-05 \\
(6.79 \mathrm{e}-05)\end{array}$ \\
\hline Z, Exports & $\begin{array}{l}0.293 * * * \\
(0.0318)\end{array}$ & $\begin{array}{l}0.173 * * * \\
(0.0192)\end{array}$ & $\begin{array}{c}0.000597 * * * \\
(0.000146)\end{array}$ & $\begin{array}{l}0.288 * * * \\
(0.0314)\end{array}$ & $\begin{array}{l}0.170^{* * * *} \\
(0.0191)\end{array}$ & $\begin{array}{c}0.000459^{* * * *} \\
(0.000122)\end{array}$ \\
\hline IP, Imports & $\begin{array}{l}0.102 * * \\
(0.0479)\end{array}$ & $\begin{array}{l}0.0356^{*} \\
(0.0200)\end{array}$ & $\begin{array}{c}0.000181 \\
(0.000172)\end{array}$ & $\begin{array}{l}0.0974 * * \\
(0.0458)\end{array}$ & $\begin{array}{l}0.0343^{*} \\
(0.0196)\end{array}$ & $\begin{array}{c}0.000128 \\
(0.000129)\end{array}$ \\
\hline $\mathrm{G}$, Sales growth & $\begin{array}{c}-0.00535 * * * \\
(0.00206)\end{array}$ & $\begin{array}{c}-0.00250 * * \\
(0.00127)\end{array}$ & $\begin{array}{c}-4.39 \mathrm{e}-05^{* *} \\
(2.02 \mathrm{e}-05)\end{array}$ & $\begin{array}{c}-0.00488 * * \\
(0.00202)\end{array}$ & $\begin{array}{l}-0.00207^{*} \\
(0.00124)\end{array}$ & $\begin{array}{c}-4.75 \mathrm{e}-05^{* *} \\
(1.98 \mathrm{e}-05)\end{array}$ \\
\hline $\begin{array}{l}\text { FO, Foreign } \\
\text { ownership }\end{array}$ & $\begin{array}{l}0.0416 * * * \\
(0.00915)\end{array}$ & $\begin{array}{c}0.00516 \\
(0.00411)\end{array}$ & $\begin{array}{c}0.000524 * * * \\
(0.000132)\end{array}$ & $\begin{array}{l}0.0482 * * * \\
(0.00942)\end{array}$ & $\begin{array}{l}0.00854 * * \\
(0.00425)\end{array}$ & $\begin{array}{c}0.000460 * * * \\
(0.000119)\end{array}$ \\
\hline s, Spread & & & & $\begin{array}{l}0.0353 * * \\
(0.0143)\end{array}$ & $\begin{array}{c}0.0152 * \\
(0.00857)\end{array}$ & $\begin{array}{c}0.000468 * * * \\
(0.000122)\end{array}$ \\
\hline $\begin{array}{l}\mathrm{c}, \text { Credit to private } \\
\text { sector }\end{array}$ & & & & $0.0998^{* * *}$ & $0.119 * * *$ & $-0.00117 * * *$ \\
\hline & & & & $(0.0244)$ & $(0.0163)$ & $(0.000271)$ \\
\hline $\mathrm{RE}$ & YES & YES & YES & YES & YES & YES \\
\hline Time Effects & YES & YES & YES & NO & NO & NO \\
\hline $\begin{array}{l}\text { Number of } \\
\text { Observations }\end{array}$ & 34,064 & 34,064 & 34,064 & 34,064 & 34,064 & 34,064 \\
\hline Number of firms & 5,012 & 5,012 & 5,012 & 5,012 & 5,012 & 5,012 \\
\hline
\end{tabular}

Source: Authors calculations based on SS, DIAN-DANE, SFC and BdR.

Note: Robust standard error in parenthesis. ${ }^{* * *} \mathrm{p}<0.01,{ }^{*} \mathrm{p}<0.05,{ }^{*} \mathrm{p}<0.1$

Specifications (1) - (3) use time effects in place of the macroeconomic variables and specifications. Specifications (7) and (8) include the interactions of macro variables with firmlevel characteristics.

As Table 6 shows, all coefficients of firm level, noninteracted and interacted macroeconomic variables are significant at the 10 percent confidence level. In general terms, the determinants for all types of FC debt behave as expected. The shares of total and financial FC debt to total assets increase with size, leverage, short term debt, and exports to total sales-evidence yet again of natural hedging - and decrease with the ratio of imports to total expenses. Both FC debt measures are procyclical with respect to domestic bank credit. In contrast, the 


\section{Table 6. Determinants of the Share of FC Debt Issued}

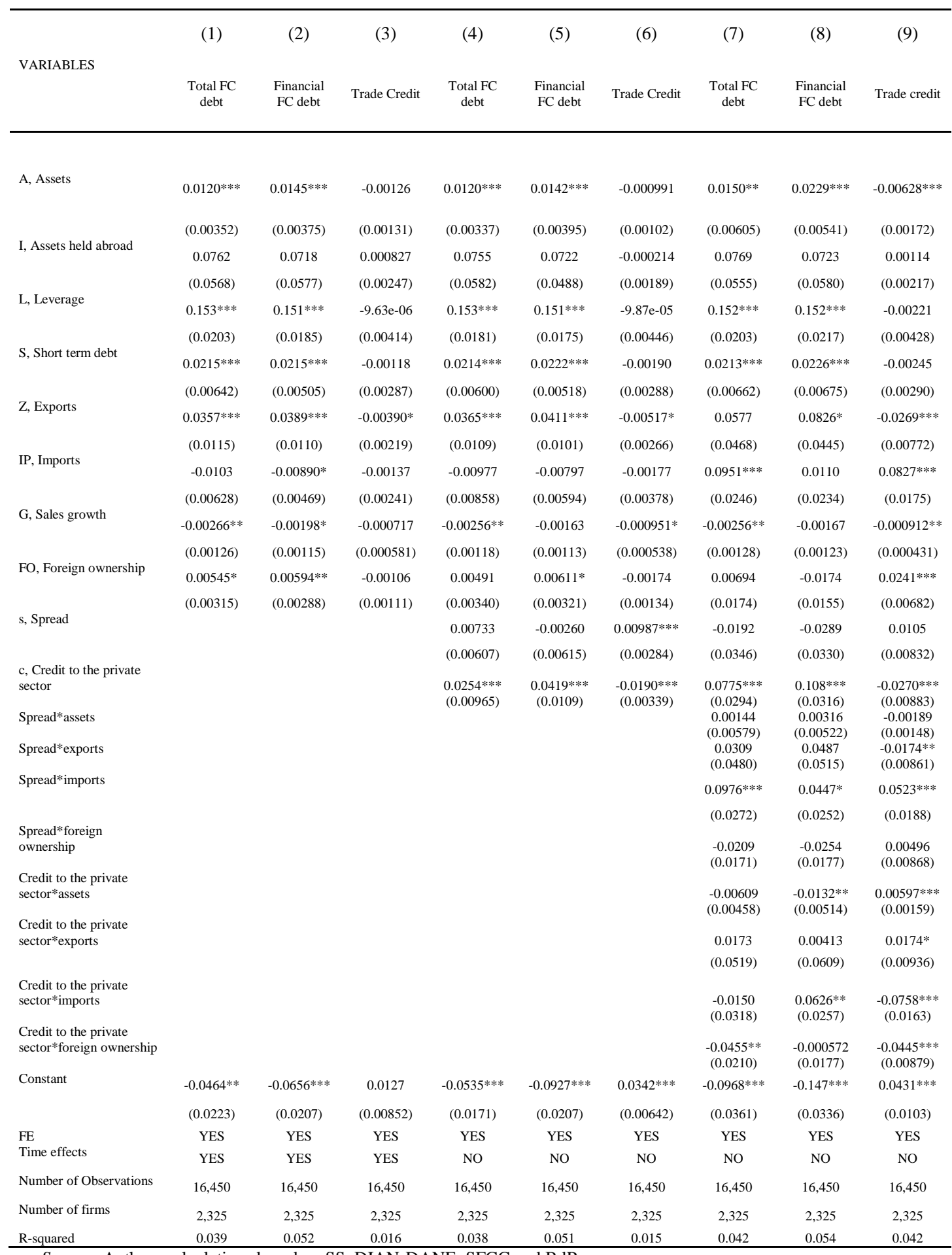

Source: Authors calculations based on SS, DIAN-DANE, SFCC and BdR.

Note: Standard errors estimated by bootstrapping in parentheses. *** $\mathrm{p}<0.01, * * \mathrm{p}<0.05, * \mathrm{p}<0.1$ 
corresponding regression for trade credit shows markedly different behavior; size and exports have a negative sign; imports are positive; and trade credit behaves countercyclically with respect to domestic bank credit. However, some effects are common across all three types of FC debt: they all decrease with sales growth-giving support to the idea that FC debt substitutes for self-finance - and increase if the firm is owned by foreigners.

With respect to the interaction with macroeconomic variables, the larger the exports-to-totalrevenue ratio, the more sensitive the use of trade credit to the interest spread. Firms that export more are also less likely to show a countercyclical use of trade credit with respect to domestic bank credit. Also, for larger or foreign-owned firms, the use of financial FC debt is less procyclical, presumably because swings in domestic bank credit have a smaller effect on their access to financing. Firms that import more tend to be more sensitive to the spread and their use of FC financial debt is more procyclical while their use of trade credit is less procyclical with respect to swings in domestic bank credit.

\section{B. Investment and the Currency Composition of Debt}

Now that we have a good grasp of the factors driving FC liabilities, we turn to exploring whether such indebtedness can be a source of vulnerability by transmitting exchange rate shocks to real activity. Specifically, we will test whether the investment by firms that have built up FC liabilities tends to be more sensitive to exchange-rate fluctuations. This issue was first addressed in Restrepo, Cuervo, and Montes (2014), using a static panel regression approach. We improve upon this analysis by adopting a more appropriate dynamic panel estimation method (Arellano and Bond, 1991; Arellano and Bover, 1995; Blundell and Bond, 1998) for which our database is well suited given that (i) we have few periods and many firms; (ii) a linear functional relationship seems reasonable ${ }^{21}$; (iii) the dependent variable, firm-level investment, is dynamic, a function of its past realizations; (iv) independent variables are not strictly exogenous; (v) firm-level fixed effects need to be accounted for; and (vi) there is likely to be heteroskedasticity and autocorrelation within individuals but not across them. The model we estimate is the following:

$$
I N V_{i t}=\sum_{j=1}^{2} \alpha_{j} I N V_{i, t-j}+\sum_{j=0}^{2} \Delta e_{t} * F C E_{i, t-j} \beta_{1}+w_{i, t-j} \beta_{2}+\vartheta_{i}+y_{t}+\varepsilon_{i t} \quad i=1, \ldots, N \quad t=1, \ldots, 9
$$

We include yearly dummy variables $\left(y_{t}\right)$ and firm-specific fixed effects $\left(\vartheta_{i}\right)$. Yearly dummies capture aggregate shocks common to all firms, including changes in the exchange rate. Firm-

\footnotetext{
${ }^{21}$ Linearity may seem to be a strong assumption, given that vulnerabilities tend to be nonlinear. However, the precise effect we are trying to capture is nonlinear in that the sensitivity of investment to exchange rate changes is itself a function of the degree of FC exposure of the firm. Furthermore, the dynamic panel technique we use considers the persistent nature of the investment variable in the estimation. In an additional exercise reported in Table 9, we explore further nonlinearities by estimating a quantile regression for investment.
} 
specific fixed effects capture differences among firms in their optimal capital stock, which we presume does not change over our sample period.

$I N V_{i t}:$ Fixed investment by firm $i$ in period $t$

$y_{t}$ : Year dummies (exogenous)

$\Delta e_{t} * F C E_{i t}$ : the interaction between the change in the log of the real exchange rate with either FC debt, FC assets, Net exports, Net forwards or balance sheet exposure measures

$w_{i t}$ : Predetermined and endogenous variables

$\vartheta_{i}$ : Panel effects (which might be correlated with the covariables)

$\varepsilon_{i t}:$ i.i.d error term with variance $\sigma_{\epsilon}^{2}$.

We estimate five specifications of (3) for our sample of firms during 2005-13. All five specifications use two-stage GMM and report GMM standard errors (Table 7). The dependent variable appears with two lags, which establishes the limit to the lags for the instruments. ${ }^{22}$ Annex $G$ reports the instruments used in each specification as well as the Arellano-Bond test of no autocorrelation of first differences in the error term and the Sargan test for overidentification of restrictions. Both tests confirm the validity of our specification-i.e., there is zero autocorrelation of the first difference of the error term, and overidentification of restrictions are valid.

We begin with a very basic specification and progressively include additional relevant predetermined and endogenous variables. In all specifications, our variable of interest is the interaction between the change in the log of the real exchange rate with one or more measures of FC exposure and with net exports [specifications (3) and (4)]. The results show that both FC debt and FC assets transmit exchange rate fluctuations to investment, as expected. In particular, when a depreciation occurs, firms with higher FC debt (or lower FC assets) will register lower investment relative to other firms. Thus, for a given level of FC debt, having FC assets can reduce the sensitivity of firm-level investment to exchange-rate fluctuations. Similarly, having larger net exports - a natural hedge - is associated with a higher level of investment when a depreciation occurs, also dampening the cutback in investment when the firm holds FC debt.

These effects are summarized in Specification (5), where we include both the summary FC balance-sheet exposure variable-i.e., the difference between FC debt, FC assets, and net

\footnotetext{
${ }^{22}$ Endogenous and predetermined variables are optional, with restrictions regarding the number of instruments used. Option endogenous in the software is used to indicate that the variables appear as contemporary regressors.
} 
forward position - and net exports. As expected, the coefficient of the lagged interaction between the change in the real exchange rate and FC balance sheet exposure is negative and significant, indicating that a real exchange depreciation (appreciation) would have a stronger contractionary (expansionary) effect on investment for firms exhibiting a larger FC balance sheet exposure, which then can be offset by the firms' natural hedge of net exports ${ }^{23}$.

Using the estimated sensitivities from Column (5) of Table 7, a 40-percent depreciation of the real exchange rate - similar to what was observed in Colombia between 2013 and 2015causes, ceteris paribus, a 4.7 percent decline in investment for the following period of those firms with a ratio of $\mathrm{FC}$ balance sheet exposure to total assets of 0.5 compared to those with a ratio of zero-i.e., when a firm perfectly matches net forwards, FC assets, and liabilities, or when it holds neither of them. ${ }^{24}$

This balance sheet effect on investment is quantitatively small. Nonetheless, if we consider that our sample period is characterized by an almost continuous real exchange-rate appreciationthe only annual depreciation occurring in 2009 - the marginal effect could be a consequence of an asymmetric response of investment to exchange-rate fluctuations ${ }^{25}$. Indeed, it may be possible that investment reacts more strongly to depreciations than to appreciations. To test this, we perform an event study comparing pre- and post-depreciation levels of investment. We run a cross-section regression in which the dependent variable is the difference between fixed capital investment in 2009 and the 2005-08 average.

We estimate two specifications, where all explanatory variables are taken at their 2008 levels. In the first one, we include total liabilities, FC debt, FC assets, net exports, net forwards, and cash flow as controls. ${ }^{26}$ In the second one, we include the FC balance sheet exposure, net exports, and cash flow. Results in Table 8 show that all coefficients are significant, at a 1 percent confidence level, and that the change in investment was greater for firms that had larger FC assets, net exports, or cash-flow, and less FC debt.

\footnotetext{
${ }^{23}$ Annex $\mathrm{H}$ shows the same regressions for all firms, including those appearing in the database for less than 5 years (unbalanced panel database). The results are quantitatively and qualitatively similar, which greatly mitigates concerns about sample selection bias.

${ }^{24}$ The calculation is as follows: we take the value of the coefficient of lagged balance-sheet exposure* $\log (\mathrm{e})(\mathrm{i} . \mathrm{e} .,-$ $0.2375)$, multiply it by 0.5 and then by 0.4 .

${ }^{25}$ It would have also been highly illuminating to conduct a similar event study surrounding 2014, when the exchange rate depreciated by over 60 percent, but data limitations prevented this. In particular, a change in accounting standards caused widespread reporting errors to the SSF in 2014.

${ }^{26}$ All defined as in (3).
} 
Table 7. Fixed Capital Investment and Foreign Currency Exposure

\begin{tabular}{|c|c|c|c|c|c|}
\hline VARIABLES & (1) & (2) & (3) & (4) & (5) \\
\hline \multicolumn{6}{|l|}{ Investment } \\
\hline \multirow{3}{*}{ L1.investment } & & & $0.0393904 * *$ & $0.0379099 * *$ & \\
\hline & 0.0400021 & 0.0316133 & $*$ & $*$ & 0.0291733 \\
\hline & $(0.0265326)$ & $(0.0223653)$ & $(0.0196291)$ & $(0.0166994)$ & $(0.0181737)$ \\
\hline \multirow[t]{2}{*}{ L2.investment } & -0.0042935 & -0.0045869 & -0.0066719 & -0.0036328 & -0.0032565 \\
\hline & $(0.0041361)$ & $(0.003895)$ & $(0.0042093)$ & $(0.0033247)$ & $(0.0032511)$ \\
\hline \multirow[t]{2}{*}{ FC Debt*loge } & 0.1261524 & 0.0543272 & -0.0004291 & -0.0040576 & \\
\hline & $(0.139509)$ & $(0.1305649)$ & $(0.1305644)$ & $(0.1134087)$ & \\
\hline \multirow{3}{*}{ L1.FC Debt*loge } & & $0.247867 * *$ & & & \\
\hline & $-0.2002081^{*}$ & * & $-0.289505^{* * *}$ & $-0.242204 * * *$ & \\
\hline & $(0.1089441)$ & $(0.1083235)$ & $(0.1163331)$ & $(0.0926381)$ & \\
\hline \multirow{3}{*}{ L2.FC Debt*loge } & & $0.163660^{* *}$ & & & \\
\hline & -0.1185677 & $*$ & $-0.204202 * * *$ & $-0.168674 * * *$ & \\
\hline & $(0.086714)$ & $(0.0796475)$ & $(0.0796276)$ & $(0.0632029)$ & \\
\hline \multirow[t]{2}{*}{ FC Assets*loge } & & 0.3836653 & 0.5942126 & 0.5896773 & \\
\hline & & $(0.5194815)$ & $(0.5085229)$ & $(0.4201533)$ & \\
\hline \multirow[t]{2}{*}{ L1.FC Assets*loge } & & 0.2614103 & 0.5050653 & $0.5904368^{*}$ & \\
\hline & & $(0.4053163)$ & $(0.3854882)$ & $(0.3259041)$ & \\
\hline \multirow[t]{2}{*}{ L2.FC Assets*loge } & & -0.0887787 & 0.101349 & 0.1968064 & \\
\hline & & $(0.2456334)$ & $(0.2183617)$ & $(0.1922558)$ & \\
\hline \multirow[t]{2}{*}{ Net exports*loge } & & & 0.0256163 & 0.0137071 & 0.0178542 \\
\hline & & & $(0.0239917)$ & $(0.0243016)$ & $(0.0196483)$ \\
\hline \multirow[t]{2}{*}{ L1.Net exports*loge } & & & 0.0184767 & 0.0230599 & 0.0023265 \\
\hline & & & (0.0190096) & $(0.0189395)$ & $(0.0165825)$ \\
\hline \multirow[t]{2}{*}{ L2.Net exports*loge } & & & 0.0083432 & 0.0118951 & 0.0094871 \\
\hline & & & $(0.0102282)$ & $(0.0089674)$ & $(0.0093734)$ \\
\hline \multirow[t]{2}{*}{ Net Fwds*loge } & & & & 0.0028193 & \\
\hline & & & & $(0.206213)$ & \\
\hline \multirow[t]{2}{*}{ L1.Net Fwds*loge } & & & & -0.1129638 & \\
\hline & & & & $(0.1622304)$ & \\
\hline \multirow[t]{2}{*}{ L2.Net Fwds*loge } & & & & 0.0375458 & \\
\hline & & & & $(0.0581135)$ & \\
\hline $\begin{array}{l}\text { Balance-sheet } \\
\text { exposure*loge }\end{array}$ & & & & & 0.0052498 \\
\hline
\end{tabular}




\begin{tabular}{|c|c|c|c|c|c|}
\hline VARIABLES & (1) & (2) & (3) & (4) & (5) \\
\hline & & & & & $(0.095137)$ \\
\hline $\begin{array}{l}\text { L1.Bal-sheet } \\
\text { exposure*loge }\end{array}$ & & & & & $\begin{array}{r}-0.237570^{* * *} \\
(0.0936734)\end{array}$ \\
\hline $\begin{array}{l}\text { L2.Bal-sheet } \\
\text { exposure*loge }\end{array}$ & & & & & $\begin{array}{r}-0.105292 * * * \\
(0.0505935)\end{array}$ \\
\hline FC Debt & $\begin{array}{r}0.0248178 \\
(0.0419646)\end{array}$ & $\begin{array}{r}0.0077866 \\
(0.0335359)\end{array}$ & $\begin{array}{r}-0.0188403 \\
(0.0254842)\end{array}$ & $\begin{array}{l}-0.0142983 \\
(0.022251)\end{array}$ & \\
\hline L1.FC Debt & $\begin{array}{r}-0.0306018 \\
(0.0439202)\end{array}$ & $\begin{array}{l}-0.0409641 \\
(0.0349951)\end{array}$ & $\begin{array}{r}-0.023536 \\
(0.0299221)\end{array}$ & $\begin{array}{l}-0.0224217 \\
(0.0208303)\end{array}$ & \\
\hline \multirow{2}{*}{ L2.FC Debt } & $-0.0425949 * *$ & $\begin{array}{r}0.045740 * * \\
*\end{array}$ & $-0.053140 * * *$ & $-0.036574 * * *$ & \\
\hline & $(0.0202256)$ & $(0.0179017)$ & $(0.0161653)$ & $(0.0139491)$ & \\
\hline \multirow[t]{2}{*}{ FC Assets } & & 0.0808392 & 0.0755256 & 0.055149 & \\
\hline & & $(0.0642422)$ & $(0.0647141)$ & $(0.0471132)$ & \\
\hline \multirow[t]{2}{*}{ L1.FC Assets } & & -0.0224295 & -0.0034936 & 0.003136 & \\
\hline & & $(0.0722707)$ & $(0.0658005)$ & $(0.0584454)$ & \\
\hline \multirow[t]{2}{*}{ L2.FC Assets } & & -0.0136979 & 0.012501 & 0.0350523 & \\
\hline & & $(0.044191)$ & $(0.0402987)$ & $(0.0347521)$ & \\
\hline \multirow[t]{2}{*}{ Balance-sheet exposure } & & & & & $0.0052498 * *$ \\
\hline & & & & & $(0.095137)$ \\
\hline \multirow[t]{2}{*}{ L1.Bal-sheet exposure } & & & & & $-0.237570 * * *$ \\
\hline & & & & & $(0.0936734)$ \\
\hline \multirow[t]{2}{*}{ L2.Bal-sheet exposure } & & & & & $-0.105292 * * *$ \\
\hline & & & & & $(0.0505935)$ \\
\hline \multirow[t]{2}{*}{ Net exports } & & & 0.0161176 & 0.0104457 & 0.0045017 \\
\hline & & & $(0.0100681)$ & (0.0072086) & $(0.0080419)$ \\
\hline \multirow[t]{2}{*}{ L1.Net exports } & & & -0.0018225 & 0.0022666 & 0.0022884 \\
\hline & & & $(0.0084931)$ & $(0.0054585)$ & $(0.0069497)$ \\
\hline \multirow[t]{3}{*}{ L2.Net exports } & & & -0.0052771 & $-0.005432 * * *$ & $-0.0053933 * *$ \\
\hline & & & $(0.0034588)$ & $(0.0024374)$ & $(0.0026583)$ \\
\hline & & & $0.0604837 * *$ & & \\
\hline \multirow{2}{*}{ Total liabilities } & 0.0205201 & 0.03377 & $*$ & $0.032424 * * *$ & 0.0057476 \\
\hline & $(0.0360688)$ & $(0.02756)$ & $(0.0205746)$ & $(0.0121736)$ & $(0.0143866)$ \\
\hline
\end{tabular}




\begin{tabular}{|c|c|c|c|c|c|}
\hline VARIABLES & (1) & (2) & (3) & (4) & (5) \\
\hline L1.Total liabilities & -0.004575 & 0.0065246 & -0.0180888 & -0.0103422 & 0.0028232 \\
\hline & $(0.0330919)$ & $(0.0252721)$ & $\begin{array}{r}(0.0189499) \\
0.0132748 * *\end{array}$ & $(0.0102732)$ & $(0.0123613)$ \\
\hline L2.Total liabilities & 0.0127747 & 0.010858 & * & 0.0081869 & $0.0083662 *$ \\
\hline & $(0.0087978)$ & $(0.0080635)$ & $(0.0058197)$ & $(0.0050553)$ & $(0.0050439)$ \\
\hline \multirow[t]{2}{*}{ Net Fwds } & & & & -0.0286693 & \\
\hline & & & & (0.0209937) & \\
\hline \multirow[t]{2}{*}{ L1.Net Fwds } & & & & -0.0086595 & \\
\hline & & & & $(0.0228929)$ & \\
\hline \multirow[t]{2}{*}{ L2.Net Fwds } & & & & 0.0111916 & \\
\hline & & & & $(0.0079531)$ & \\
\hline \multirow[t]{3}{*}{ Cash flow } & 0.0213787 & 0.0029615 & -0.0336025 & -0.0321964 & $-0.0840524 * *$ \\
\hline & $(0.0649214)$ & $(0.0494949)$ & $(0.041712)$ & $(0.0350876)$ & $(0.0450702)$ \\
\hline & & & $0.0867867 * *$ & $0.0888847 * *$ & $0.1126343^{* *}$ \\
\hline \multirow[t]{2}{*}{ L1.Cash flow } & -0.0173726 & 0.027032 & $*$ & $*$ & * \\
\hline & $(0.0451006)$ & $(0.0365184)$ & $(0.0265526)$ & $(0.0210349)$ & $(0.0249856)$ \\
\hline \multirow[t]{3}{*}{ L2.Cash flow } & -0.0003964 & 0.0014331 & -0.0228276 & $-0.035847 * * *$ & $-0.039687 * * *$ \\
\hline & $(0.0203149)$ & $(0.0181671)$ & $(0.022013)$ & $(0.0157341)$ & $(0.0170571)$ \\
\hline & & $0.0229624^{-}$ & & & \\
\hline \multirow[t]{2}{*}{ Constant } & -0.0106651 & $*$ & $-0.024306 * * *$ & $-0.011674 * * *$ & -0.0046201 \\
\hline & $(0.0143341)$ & $(0.0116976)$ & $(0.0076186)$ & $(0.0059327)$ & $(0.0061613)$ \\
\hline Observations & 22957 & 22957 & 22957 & 22957 & 22957 \\
\hline Number of firms & 4961 & 4961 & 4961 & 4961 & 4961 \\
\hline
\end{tabular}

Source: Author's calculations based on SS, SFCC, DIAN-DANE and BdR.

Note: The dependent variable is the change in the stock of fixed capital in millions of COP adjusted by the CPI. All variables (except dummies) are scaled by previous period total assets. The real exchange rate is the nominal COP/USD exchange rate divided by domestic CPI. Net forward position corresponds to the difference in nominal values of long and short positions with local banks. Standard errors in parentheses. $* * * \mathrm{p}<0.01, * * \mathrm{p}<0.05,{ }^{*} \mathrm{p}<0.1$.

That is, investment fell by less for these firms. Using the estimated coefficients, the observed real depreciation of about 3 percent would imply that firms with a ratio of FC debt to total assets of 0.5 would invest 3 percent less than firms with no FC debt - a much larger effect than what we estimated earlier using a sample period dominated by real appreciations. Similarly, firms with FC assets equivalent to 0.5 of their total assets would increase investment by 30 percent relative to firms without FC assets. Finally, firms with 0.5 of net-exports-to-assets ratio would increase their investment by 6 percent, in comparison to firms with no net exports. This provides evidence that firm-level investment seems to react much more strongly to the balance sheet effects of depreciations than to those of appreciations. 
Table 8. Balance Sheet Effect on Investment During a Depreciation Period

\begin{tabular}{lcc}
\hline VARIABLES & $(1)$ & $(2)$ \\
\hline FC debt in 2008 & $-0.0626^{* * * *}$ & \\
FC assets in 2008 & $(0.0172)$ & \\
& $0.626^{* * *}$ & \\
Net exports in 2008 & $(0.164)$ & \\
& $0.128^{* * *}$ & $0.125^{* * *}$ \\
Net Fwds in 2008 & $(0.00458)$ & $(0.00445)$ \\
& -0.00269 & \\
Balance-sheet exposure in 2008 & $(0.0323)$ & -0.0118 \\
& & $(0.0103)$ \\
Total liabilities in 2008 & & $-0.0582^{* * *}$ \\
& $-0.0524^{* * *}$ & $(0.00391)$ \\
Cash flow in 2008 & $(0.00441)$ & $0.293^{* * *}$ \\
& $0.286^{* * * *}$ & $(0.00509)$ \\
Constant & $(0.00564)$ & -0.550 \\
& -2.071 & $(3.559)$ \\
Observations & $(3.570)$ & 4,244 \\
R-squared & & 0.931 \\
\hline
\end{tabular}

Source: Author's calculations based on SS, SFCC, DIAN-DANE and BdR.

Note: Standard errors in parentheses. $* * * \mathrm{p}<0.01, * * \mathrm{p}<0.05, * \mathrm{p}<0.1$.

To explore further nonlinearities in the response of investment to exchange rate fluctuations, we also ran a quantile regression, ${ }^{27}$ where the dependent variable is investment in fixed capital as a ratio of assets, and the key explanatory variable is the balance sheet exposure. ${ }^{28}$ As Table 9 shows, balance sheet exposure has a negative and significant effect on the investment rate from the seventh to the ninth decile. As expected, the effect of balance sheet exposure on the investment rate is not the same across firms.

While a firm in the seventh decile with a 0.5 balance-sheet-exposure-to-total-assets ratio would decrease its investment by 0.9 percent in comparison to a firm without balance sheet exposure, a firm in the ninth decile would decrease its investment by 5 percent. The larger the investment rate of the firm, the greater the reduction in investment caused by the balance sheet exposure. Firms who invest the most are the ones that suffer the most because of their balance sheet exposure.

\footnotetext{
${ }^{27}$ Standard linear regression techniques summarize the average relationship between a set of regressors and the outcome variable, based on the conditional mean function. Quantile regression allows us to describe the relationship at different points of the conditional distribution of the outcome variable.

${ }^{28}$ Other control variables are net exports, total liabilities, and cash flow. All as defined in Equation (1).
} 


\section{Determinants of the Use of Exchange-Rate Derivatives}

One surprising stylized fact that emerges from the descriptive statistics (Annex B) is that firms on average tend to have short positions in FC forwards regardless of whether they are indebted in FC or not. In addition, results from Section 3.2 show that forward exchange derivatives on their own do not have any effect on the sensitivity of investment to exchange-rate fluctuations. Thus, it is not clear if these instruments are being used for hedging purposes. We propose the following equation to gain some insight on the determinants of the use of forward-exchange derivatives (FEDs):

$$
\begin{gathered}
F E D_{i, t}=\alpha_{i}+\beta_{1} A_{i, t}+\beta_{2} L_{i, t}+\beta_{3} Z_{i, t}+\beta_{4} F O_{i, t}+\beta_{5} G_{i, t}+\beta_{6} I_{i, t} \\
+\beta_{7} S_{i, t}+\beta_{8} I P_{i, t}+\beta_{9} F C S_{i, t}+\rho_{1} S_{t}+\rho_{2} f_{t}+\rho_{3} N E R_{t}+\gamma_{1} C B P_{t}+\gamma_{2} C B S_{t}+e_{i, t}
\end{gathered}
$$

All firm-level variables are defined as in (1). To test whether FC derivatives are used to hedge FC debt servicing obligations, we include an additional term not in (1): FCS, the share of FC debt in total liabilities. We also include three macro variables: the interest rate differential (the difference between the interbank rate and the overnight LIBOR), the forward premium, and NER (the annual average nominal exchange rate). This last variable will help us test whether firms increase the use of FEDs as a hedging mechanism in the face of strong exchange rate depreciations/appreciations.

In addition, we included $C B P$ (central bank total foreign-exchange purchases per year) and $C B S$ (central bank total foreign-exchange sales per year), to capture whether FED strategies of Colombian firms are affected by central-bank intervention in the foreign exchange market. It is important to take into the account that, even though Colombia operates under inflation targeting with a (de jure) floating exchange rate, there is empirical and anecdotal evidence that, at times, the Central Bank has been involved to some degree in exchange-rate targeting, especially in the face of large external shocks. For example, Barajas et al. (2014) find evidence that, in Colombia and in three other Latin American inflation targeters, intervention can be characterized by a reaction function, where central bank purchases and sales of foreign exchange respond to exchange rate misalignments, measured as a deviation of the real exchange rate from its long-term trend. Furthermore, they find that intervention is asymmetric: more aggressive in responding to appreciations than to depreciations. This implicit targeting of the exchange rate by the Colombian central bank might influence the firm's hedging behavior.

We use three different definitions for $F E D$. The first $F E D$ is a dummy variable that takes the value of 1 if the firm had any position in forward-exchange derivatives, 0 otherwise. The second FED takes a value of 1 only if the firm has a long position, 0 otherwise. The third FED takes a value of 1 only if the firm has a short position, 0 otherwise. For each definition, we run an alternative specification in which we exclude the macro variables and include time effects. 
Table 9. Quantile regression:

The effect of Balance Sheet Exposure on Investment by Deciles of Investment (2009)

\begin{tabular}{|c|c|}
\hline VARIABLES & \\
\hline $\begin{array}{l}\text { First decile of } \\
\text { investment }\end{array}$ & $\begin{array}{c}0.01204 \\
(0.01516)\end{array}$ \\
\hline $\begin{array}{l}\text { Second decile of } \\
\text { investment }\end{array}$ & $\begin{array}{c}0.00821 \\
(0.00507)\end{array}$ \\
\hline $\begin{array}{c}\text { Third decile of } \\
\text { investment }\end{array}$ & $\begin{array}{c}0.00338 \\
(0.00380)\end{array}$ \\
\hline $\begin{array}{l}\text { Fourth decile of } \\
\text { investment }\end{array}$ & $\begin{array}{c}0.00099 \\
(0.00195)\end{array}$ \\
\hline $\begin{array}{l}\text { Fifth decile of } \\
\text { investment }\end{array}$ & $\begin{array}{l}-0.00032 \\
(0.00284)\end{array}$ \\
\hline $\begin{array}{l}\text { Sixth decile of } \\
\text { investment }\end{array}$ & $\begin{array}{l}-0.00569 \\
(0.00572)\end{array}$ \\
\hline $\begin{array}{l}\text { Seventh decile of } \\
\text { investment }\end{array}$ & $\begin{array}{c}-0.01797 * \\
(0.00999)\end{array}$ \\
\hline $\begin{array}{l}\text { Eight decile of } \\
\text { investment }\end{array}$ & $\begin{array}{c}-0.03914 * \\
(0.02060)\end{array}$ \\
\hline $\begin{array}{l}\text { Ninth decile of } \\
\text { investment }\end{array}$ & $\begin{array}{r}-0.09846 * * \\
(0.04084)\end{array}$ \\
\hline $\begin{array}{c}\text { Firm level controls } \\
\text { Observations }\end{array}$ & $\begin{array}{c}\text { YES } \\
4,627\end{array}$ \\
\hline
\end{tabular}

Source: Authors calculations based on SS, DIAN-DANE, SFCC and BdR.

Note: Robust standard errors in parentheses. ${ }^{* * *} \mathrm{p}<0.01,{ }^{* *} \mathrm{p}<0.05,{ }^{*} \mathrm{p}<0.1$

All firm-level variables are significant at least at the 10-percent level of confidence (Table 10). ${ }^{29}$ The size of the firm is a positive determinant of participation in forward markets, which could be related to scale economies in the FC forward market. FCS, the size of FC liabilities, is associated with a higher probability of using FC forwards and of having a long position consistent with a hedging motive. On the other hand, FCS is also associated with a higher probability of having short FC forward positions, not consistent with hedging. Exports are positively related to taking FED long positions and negatively related to taking short

${ }^{29}$ Results are robust when run as a probit model. See Annex I. 
positions, suggesting that export-oriented firms use derivatives as a complement or in addition to natural hedging of their FC debt. For importing firms, if FEDs are used to hedge FC debt or other future outlays in foreign currency, they should have a higher probability of being in a long FED position and a lower probability of being in a short FED position. However, we find the opposite. These firms are more likely to be in a short position, evidence that forwardexchange derivatives are not being used entirely for hedging reasons. Another interesting result is that foreign-owned firms tend to be long on FC, while domestic firms tend to be short. This could be reflecting alternative strategies by multinational companies to hedge exchange-rate risk across markets and Colombian subsidiaries in domestic markets. Finally, the probability of having a short position increases with leverage and short-term debt and decreases with the growth of sales.

To shed further light on the results for firm-level characteristics, we refer to a survey of a sample of 12 large Colombian firms conducted during 2015-16, which is described in detail in Barajas et al (2016). More than half of the firms surveyed do not financially hedge their balance sheet exposure ${ }^{30}$ at all, and less than a quarter hedge more than 25 percent of their exposure. ${ }^{31}$ This might be related to the relatively high natural match they report to have between their operating revenue, costs, and financial debt. Nevertheless, most firms are still active in FC derivatives markets, as more than half of surveyed firms report to have used futures or forward contracts to manage FC risk. In conclusion, although firms are active in the FC derivatives markets, only a small proportion of firms report use of FC derivatives to hedge their FC liabilities; and those that do, report hedging only a small portion of their exposures.

Regarding macroeconomic variables, Table 10 shows that they all are significant at a 5 percent confidence level. Somewhat counterintuitively, a higher forward premium reduces the probability of taking a long position in the FC derivatives market and increases the probability of taking a short position, meaning that, if a large depreciation is expected, firms are more likely to sell rather than buy FC forward. The interest-rate differential has a negative effect on the probability of acquiring a short position in the FC derivative market and has no effect on the long position. Notably, the more depreciated the NER is, the higher the probability of engaging in a long FED position. Finally, the central bank's foreign exchange purchases and sales have a negative effect on a firm's probability to engage in any type of FC derivative, evidence that exchange rate intervention reduces the incentive to hedge via FC forwards.

\footnotetext{
${ }^{30}$ When we asked the reasons why they did not engage in FC risk management, firms answered: (i) their exposure to FC risk was low; (ii) they could manage it more effectively by other means; (iii) accounting treatment complexity; and (iv) costs of establishing and maintaining a risk management program exceed the expected benefits.

${ }^{31}$ The concept in the surveys that is the closest to our balance sheet exposure definition is the "translation exposure," and it refers to the risk that the firm's assets, equity, liabilities, or income change in value due to fluctuations in exchange rates. This exposure, thus, refers to the risk that the financial figures reflected in the accounting statements will change their value because of the translation of foreign accounts into the domestic currency.
} 
Table 10. Determinants for the Use of Forward Exchange Derivatives by Firms

(Marginal effects after logit)

\begin{tabular}{|c|c|c|c|c|c|c|}
\hline VARIABLES & $\begin{array}{l}\text { Logit } \\
\text { Long or short positions }\end{array}$ & $\begin{array}{l}\text { Logit } \\
\text { Long or short positions }\end{array}$ & $\begin{array}{l}\text { Logit } \\
\text { Long position }\end{array}$ & $\begin{array}{l}\text { Logit } \\
\text { Long position }\end{array}$ & $\begin{array}{l}\text { Logit } \\
\text { Short position }\end{array}$ & $\begin{array}{l}\text { Logit } \\
\text { Short position }\end{array}$ \\
\hline Assets & $\begin{array}{l}0.00780 * * * \\
(0.000760)\end{array}$ & $\begin{array}{l}0.00787 * * * \\
(0.000758)\end{array}$ & $\begin{array}{l}0.000465 * * * \\
(9.38 \mathrm{e}-05)\end{array}$ & $\begin{array}{l}0.000462 * * * \\
(9.32 \mathrm{e}-05)\end{array}$ & $\begin{array}{l}0.00544 * * * \\
(0.000552)\end{array}$ & $\begin{array}{l}0.00551 * * * \\
(0.000553)\end{array}$ \\
\hline Assets owned abroad & $\begin{array}{l}-0.0217 \\
(0.0166)\end{array}$ & $\begin{array}{l}-0.0215 \\
(0.0162)\end{array}$ & $\begin{array}{l}-0.0011 \\
(0.000889)\end{array}$ & $\begin{array}{l}-0.00110 \\
(0.000887)\end{array}$ & $\begin{array}{l}-0.0163 \\
(0.0112)\end{array}$ & $\begin{array}{l}-0.0162 \\
(0.0109)\end{array}$ \\
\hline Leverage & $\begin{array}{l}0.0197 * * * \\
(0.00536)\end{array}$ & $\begin{array}{l}0.0197 * * * \\
(0.00534)\end{array}$ & $\begin{array}{l}0.0000491 \\
(0.000390)\end{array}$ & $\begin{array}{l}3.75 \mathrm{e}-05 \\
(0.000389)\end{array}$ & $\begin{array}{l}0.0192 * * * \\
(0.00403)\end{array}$ & $\begin{array}{l}0.0192 * * * \\
(0.00404)\end{array}$ \\
\hline FC debt & $\begin{array}{l}0.0621 * * * \\
(0.00589)\end{array}$ & $\begin{array}{l}0.0620 * * * \\
(0.00588)\end{array}$ & $\begin{array}{l}0.00139 * * * \\
(0.000388)\end{array}$ & $\begin{array}{l}0.00139 * * * \\
(0.000388)\end{array}$ & $\begin{array}{l}0.0474 * * * \\
(0.00464)\end{array}$ & $\begin{array}{l}0.0474 * * * \\
(0.00465)\end{array}$ \\
\hline Short term debt & $\begin{array}{l}0.0196 * * * \\
(0.00287)\end{array}$ & $\begin{array}{l}0.0193 * * * \\
(0.00286)\end{array}$ & $\begin{array}{l}0.0000982 \\
(0.000182)\end{array}$ & $\begin{array}{l}9.60 \mathrm{e}-05 \\
(0.000182)\end{array}$ & $\begin{array}{l}0.0179 * * * \\
(0.00241)\end{array}$ & $\begin{array}{l}0.0177 * * * \\
(0.00233)\end{array}$ \\
\hline Exports & $\begin{array}{l}0.0262 * * * \\
(0.00372)\end{array}$ & $\begin{array}{l}0.0257 * * * \\
(0.00370)\end{array}$ & $\begin{array}{l}0.000355 * * * \\
(0.000739)\end{array}$ & $\begin{array}{l}0.00357 * * * \\
(0.000744)\end{array}$ & $\begin{array}{l}-0.00512 * * \\
(0.00260)\end{array}$ & $\begin{array}{l}-0.00554 * * \\
(0.00261)\end{array}$ \\
\hline Imports & $\begin{array}{l}0.0152 * * * \\
(0.00505)\end{array}$ & $\begin{array}{l}0.00150 * * * \\
(0.00501)\end{array}$ & $\begin{array}{l}-0.0000479 \\
(0.000155)\end{array}$ & $\begin{array}{l}-4.13 e-05 \\
(0.000153)\end{array}$ & $\begin{array}{l}0.0137 * * * \\
(0.00423)\end{array}$ & $\begin{array}{l}0.0135 * * * \\
(0.00420)\end{array}$ \\
\hline Sales growth & $\begin{array}{l}-0.00194 * * * \\
(0.000603)\end{array}$ & $\begin{array}{l}-0.00195 * * * \\
(0.000600)\end{array}$ & $\begin{array}{l}-0.0000312 \\
(4.88 \mathrm{e}-05)\end{array}$ & $\begin{array}{l}-2.82 \mathrm{e}-05 \\
(4.85 \mathrm{e}-05)\end{array}$ & $\begin{array}{l}-0.00138 * * * \\
(0.000454)\end{array}$ & $\begin{array}{l}-0.00141 * * * \\
(0.000455)\end{array}$ \\
\hline Foreign Ownership & $\begin{array}{l}-0.00211^{*} \\
(0.00120)\end{array}$ & $\begin{array}{l}-0.00179 \\
(0.00120)\end{array}$ & $\begin{array}{l}0.000258^{*} \\
(0.000135)\end{array}$ & $\begin{array}{l}0.000258^{*} \\
(0.000134)\end{array}$ & $\begin{array}{l}-0.00307 * * * \\
(0.000850)\end{array}$ & $\begin{array}{l}-0.00283 * * * \\
(0.000853)\end{array}$ \\
\hline Interest rate differential & & $\begin{array}{l}-0.153 * * * \\
(0.0249)\end{array}$ & & $\begin{array}{l}-0.00132 \\
(0.00208)\end{array}$ & & $\begin{array}{l}-0.105^{* * *} \\
(0.0186)\end{array}$ \\
\hline Forward Premium & & $\begin{array}{l}-0.00368 \\
(0.00685)\end{array}$ & & $\begin{array}{l}-0.00160 * * \\
(0.000694)\end{array}$ & & $\begin{array}{l}0.0109 * * \\
(0.00517)\end{array}$ \\
\hline Exchange rate & & $\begin{array}{l}-3.18 \mathrm{e}-06 \\
(7.54 \mathrm{e}-06)\end{array}$ & & $\begin{array}{l}1.64 \mathrm{e}-06 * * \\
(7.37 \mathrm{e}-07)\end{array}$ & & $\begin{array}{l}-2.12 \mathrm{e}-06 \\
(5.57 \mathrm{e}-06)\end{array}$ \\
\hline CB Purchases & & $\begin{array}{l}-1.64 \mathrm{e}-06 * * * \\
(4.06 \mathrm{e}-07)\end{array}$ & & $\begin{array}{l}5.08 \mathrm{e}-09 \\
(3.30 \mathrm{e}-08)\end{array}$ & & $\begin{array}{l}-1.32 \mathrm{e}- \\
06 * * * \\
(3.08 \mathrm{e}-07)\end{array}$ \\
\hline CB Sales & & $\begin{array}{l}-1.44 \mathrm{e}-05^{* * *} \\
(4.13 \mathrm{e}-06)\end{array}$ & & $\begin{array}{l}-1.78 \mathrm{e}-06 * * * \\
(1.85 \mathrm{e}-07)\end{array}$ & & $\begin{array}{l}-7.90 \mathrm{e}- \\
06 * * * \\
(3.02 \mathrm{e}-06)\end{array}$ \\
\hline $\mathrm{RE}$ & YES & YES & YES & YES & YES & YES \\
\hline Time Effects & YES & NO & YES & NO & YES & NO \\
\hline Observations & 34,064 & 34,064 & 34,064 & 34,064 & 34,064 & 34,064 \\
\hline Number of firms & 5,012 & 5,012 & 5,012 & 5,012 & 5,012 & 5,012 \\
\hline
\end{tabular}

\section{Conclusion}

As in many emerging economies, Colombia has in recent years experienced a period of surging capital inflows, in which non-financial firms have increasingly relied on international bond issuance and other foreign borrowing. With global monetary conditions now beginning to tighten and expected to tighten further, compounded with the collapse of Colombia's terms of trade, the accumulated foreign borrowing by non-financial firms is a matter of concern. At the extreme, a sharp depreciation could bankrupt firms with large currency mismatches, with severe consequences for the real economy as well for other creditors and even government 
finances. In this paper, we focus on a less extreme outcome, the possibility that vulnerable firms may need to cut back on investment as they respond to an adverse shock to their balance sheets. Our first step is to identify the determinants of foreign borrowing, then we estimate to what extent the resulting currency mismatches have affected firm investment behavior, specifically its sensitivity to exchange rate fluctuations.

We provide evidence that larger, more leveraged, foreign-owned firms are more likely to acquire FC debt. This is also true of firms engaging in international trade-either imports or exports - and of those with a higher share of short-term debt. In addition, firms tend to borrow more in FC when the interest rate differential or the forward premium is higher. Finally, we find that, overall, FC borrowing behaves procyclically with respect to domestic bank credit FC and domestic bank credit do not appear to be substitutes of each other.

We find evidence of a balance sheet effect transmitting exchange rate fluctuations to real activity. Firms with a larger FC balance-sheet mismatch reduce (increase) their investment by more following a depreciation (appreciation). On the other hand, net exports serve as a natural hedge, dampening the above effects of balance sheet exposure on investment.

Although statistically significant, the magnitude of the balance-sheet effect estimated over the entire 2005-13 sample period was relatively small, thus suggesting that there might be asymmetry in the sensitivity to depreciations versus appreciations. This was confirmed by our event study, in which we isolated the 2009 episode, the one year in which a substantial real depreciation had occurred. This exercise showed an estimated effect that was several times greater than that of the full period, which was characterized by an almost continuous appreciation.

We also studied the factors behind nonfinancial firms' decision to participate in the FC forward market. Certainly, firms carrying FC debt were more likely to do so. However, since this is the case for both short and long FC positions, it is reasonable to conclude that these instruments are not being used solely for hedging purposes. Furthermore, while exporting firms - both with and without FC liabilities - tended to complement their natural hedge with the financial hedge provided by FC forwards, importers held FC forward positions that were not consistent with hedging. This behavior by importers could be related to exchange-rate intervention by Colombian monetary authorities. As the aim of these interventions is to reduce volatility of the exchange rate, the resulting lower exchange rate risk might lessen incentives for firms to hedge with FC forwards. Also, the frequency of the data imposes several limitations for a more indepth analysis of the FC forwards market, therefore we leave this question open for future research. 


\section{References}

Arellano, M., and S. Bond. 1991. "Some Tests of Specification for Panel Data: Monte Carlo Evidence and an Application to Employment Equations." Review of Economic Studies 58(2): 277-297.

Arellano, M., and O. Bover. 1995. "Another Look at the Instrumental Variable Estimation of Error-Components Models.” Journal of Econometrics 68: 29-51.

Barajas, A. et al. 2014. "Singular Focus or Multiple Objectives? What the Data Tell Us about Inflation Targeting in Latin America." Economía: Journal of the Latin American and Caribbean Economic Association 15(1): 177-213.

Barajas, A, et al. 2016. "Balance Sheet Effects in Colombian Non-Financial Firms". Working Paper 740. Washington, DC, United States: Inter-American Development Bank.

Bleakley, H., and K. Cowan. 2002. "Corporate Dollar Debt and Devaluations: Much Ado about Nothing?” Research Department Working Paper 532. Washington, DC, United States: InterAmerican Development Bank.

Braggion, F., L. Christiano and J. Roldos. 2007. “Optimal Monetary Policy in a Sudden Stop". NBER Working Paper 13254. Cambridge, United States: National Bureau of Economic Research.

Calvo, G., A. Izquierdo and L. Mejía. 2004. "On the Empirics of Sudden Stops: The Relevance of Balance-Sheet Effects.” NBER Working Paper 10520. Cambridge, United States: National Bureau of Economic Research.

Cano, G. 2010. "Regla Fiscal y Estabilidad Macroeconómica en Colombia." Borradores de Economía 607. Bogotá, Colombia: Banco de la República.

Céspedes, L., R. Chang and A. Velasco. 2002. "IS-LM-BP in the Pampas." NBER Working Paper 9337. Cambridge, United States: National Bureau of Economic Research.

Echeverry, J. et al. 2003. "'Dollar' Debt in Colombian Firms: Are Sinners Punished during Devaluations?" Emerging Markets Review 4(4): 417-449.

Gertler, M., S. Gilchrist and F. Natalucci. 2007. "External Constraints on Monetary Policy and the Financial Accelerator". Journal of Money, Credit and Banking. Volume 39, Issue 2-4: 295330 . 
Kamil, H. 2012. "How Do Exchange Rate Regimes Affect Firms' Incentives to Hedge Currency Risk? Micro Evidence for Latin America." IMF Working Paper 12/69. Washington, DC, United States: International Monetary Fund.

Krugman, P. 1999. "Balance Sheets, the TranSFCer Problem and Financial Crises." In: P. Isard, A. Razin and A. Rose, editors. International Finance and Financial Crises. New York, United States: Kluwer Academic Publishers.

Rajan, R.G., and L. Zingales. 1998. "Financial Dependence and Growth." American Economic Review 88(3): 559-586.

Restrepo, A., N. Cuervo and E. Montes. 2014. "Descalces Cambiarios de las Firmas No Financieras.” Borradores de Economía 805. Bogotá, Colombia: Banco de la República.

Rodríguez, F., H. Kamil and B. Sutton. 2015. "Corporate Financing Trends and Balance Sheet Risks in Latin America: Taking Stock of 'The Bon(d)anza."' IMF Working Paper 15/10. Washington, DC, United States: International Monetary Fund. 


\section{Annex A. Data Availability and Variable Definition}

\begin{tabular}{|c|c|}
\hline Variable & Description \\
\hline \multicolumn{2}{|l|}{ Firm level variables } \\
\hline Total Assets & $\begin{array}{l}\text { Logarithm of real value of assets. Source: Superintendencia de Sociedades and Superintendencia } \\
\text { Financiera. }\end{array}$ \\
\hline Imports & $\begin{array}{l}\text { CIF value of goods imported plus imports of services. We convert the dollar value of exports into pesos } \\
\text { using the average exchange rate of the corresponding year. Source: DANE-DIAN. }\end{array}$ \\
\hline Exports & $\begin{array}{l}\text { FOB value of exports of goods and services. For estimation, it is normalized by total sales. We convert the } \\
\text { dollar value into pesos using the average exchange rate for the year. Source: DANE-DIAN. }\end{array}$ \\
\hline Sales & Source: SS and SFC. \\
\hline Foreign participation in Ownership & Share of company owned by foreign investors. Source: SS and SFC. \\
\hline Cash flow & A revenue or expense stream that changes a cash account over a given period. Source: SS and SFC. \\
\hline Total Profit/losses & Total income (operational+non-operational) net of total expenses and taxes. Source: SS and SFC. \\
\hline Total debt or leverage & Total liabilities (excluding net worth) as reported in balance sheets. Source: SS and SFC. \\
\hline Short- Term Debt & Debt that must be repaid within 1 year. Source: SS and SFC. \\
\hline Total "dollar" debt & Debt (including bonds) acquired by firms with foreign and domestic banks or corporations. Source: BdR. \\
\hline Tradable & $\begin{array}{l}\text { Takes the value } 1 \text { if the firm belongs to any of the following sectors: agriculture, mining or industry. Zero } \\
\text { otherwise. }\end{array}$ \\
\hline Financial debt & Source: SS and SFC. \\
\hline Long forward COP/USD & $\begin{array}{l}\text { Value of the active long cop/usd forwards at December } 31^{\text {st }} \text { of the corresponding year at firm level. Source: } \\
\text { BdR. }\end{array}$ \\
\hline Short forward COP/USD & $\begin{array}{l}\text { Value of the active short cop/usd forwards at December } 31^{\text {st }} \text { of the corresponding year at firm level. Source: } \\
\text { BdR. }\end{array}$ \\
\hline Investment in fixed capital & $\begin{array}{l}\text { Capital in t minus capital in t-1. Capital is the addition of physical properties as equipment, edification, } \\
\text { ongoing constructions, and other assets. Source: SS and SFC. }\end{array}$ \\
\hline Foreign Direct Investment & Annual net flow of FDI at firm level. Source: BdR. \\
\hline Portfolio Investment & Annual net flow of portfolio investment. Source: BdR. \\
\hline Colombian Direct Investment Abroad & Annual net flow of direct investment abroad at firm level. Source: BdR. \\
\hline \multicolumn{2}{|l|}{ Macroeconomic variables } \\
\hline Real GDP growth & Annual percentage change of real GDP. Source: DANE \\
\hline Inflation & Annual percentage change in Consumer Price index. Source: DANE \\
\hline Average Exchange Rate & Average of the exchange rate for the respective year. Source: BdR. \\
\hline Exchange Rate End of Period & Exchange rate as of December 31, of each year. Source: BdR. \\
\hline Exchange Rate Forward $^{32}$ & $\begin{array}{l}\text { Average forward rate of the COP / USD traded forwards during the period } t+1 \text { which are due in December } \\
\text { of each year. Source: BdR. }\end{array}$ \\
\hline Exchange rate forward premium & Forward Exchange Rate over Exchange Rate End of period. Source: BdR. \\
\hline Private Credit & $\begin{array}{l}\text { Total credit granted to the private sector as a percentage of GDP. Source: } \\
\text { BdR and DANE. }\end{array}$ \\
\hline
\end{tabular}

${ }^{32}$ Information regarding the position of currency derivatives firms is harder to build. Only recently regulators and investors have begun to demand more systematic information on these financial transactions. As in Restrepo et al (2014), information was used from operations of foreign currency derivatives of banks established in Colombia. We took only the forwards COP/USD, which represent about 95 percent of the total national amount of derivatives traded in Colombia. 


\section{Annex B. Descriptive Statistics for Our Sample of Firms.}

(Averages for 2005-13)

Total corporate liabilities increased from around 5 percent of total assets at the beginning of the sample to 6.2 percent in 2013; short-term debt declined from close to 80 percent of total liabilities in 2003 to 76 percent at 2013, while financial debt, defined as loans with local or foreign banks, was stable at 30 percent of total liabilities. Similarly, total FC debt (bonds, trade credit, and FC loans with local and foreign financial institutions) was relatively stable and averaged 5 percent of total liabilities. With respect to hedging instruments, net forwards as a share of total liabilities was -0.4 percent-i.e., firms sold more dollars than they bought through forward contracts. Exports averaged 6 percent of total revenue and declined during the period. Finally, the aggregate balance sheet exposure followed a path like that of FC debt, declining from 2.9 percent of total assets in 2005 to 1.8 percent in 2008 , then increasing postcrisis to 3 percent in 2013.

Figure 2 also reports descriptive statistics for net exporting and net importing firms. ${ }^{33}$ Exporting firms exhibit larger total liabilities to total assets in comparison to the whole sample of firms (7.8 percent vs 6.1 percent); they hold slightly larger shares of short-term debt (78 percent vs 76 percent), more financial debt (34 percent vs 29 percent), and significantly more FC debt (11.2 percent vs 4.9 percent). With respect to exchange rate hedging instruments, we find that exporting firms have a long position, while the entire sample has a short position (5.1 percent vs -0.4 percent). Finally, the balance sheet exposure (as a ratio of total assets) was slightly higher for exporting firms than for the whole sample (2.9 percent vs 2.5 percent).

When compared with the entire sample, importing firms display slightly smaller ratios of total liabilities to total assets (5.9 percent vs 6.1 percent) and slightly larger ratios of short-term to total debt ( 81 percent vs 76 percent) and FC to total debt (5.7 percent vs 4.9 percent), whereas the ratio of financial to total debt (29.8 percent vs 29 percent) is almost identical. Importing firms have a shorter position in exchange rate hedging instruments ( -2.2 percent vs -0.4 percent), a smaller export-to-total-revenue ratio ( 2.5 percent vs 6 percent) and, importantly, a larger balance sheet exposure ( 3.7 percent vs 2.5 percent).

Finally, exporting firms on average had a smaller balance sheet exposure in comparison to importing firms ( 2.9 percent vs 3.7 percent), caused by a longer position in exchange rate hedging ( 3.7 percent vs -2.2 percent), and a larger export-to-total-revenue ratio (37 percent vs 2.5 percent). Exporting firms might be using their $\mathrm{FC}$ revenue and the $\mathrm{FC}$ hedging instruments as complements, while the motivation for importing firms to use $\mathrm{FC}$ forwards is not immediately clear.

\footnotetext{
${ }^{33}$ Exporting (importing) firms are those that have positive (negative) values for net exports of goods and services.
} 
Figure 2. Descriptive Statistics
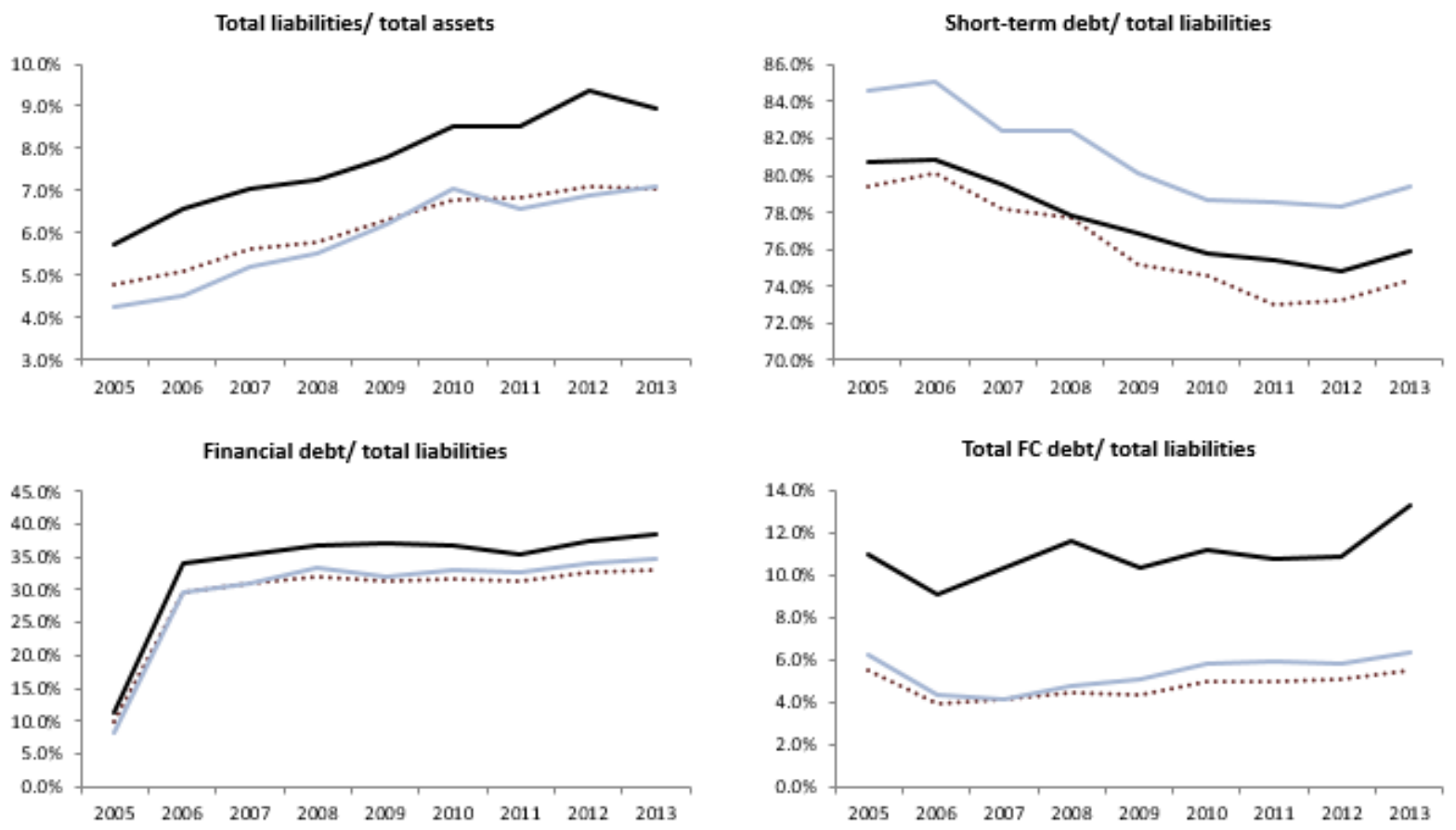

Net FC forwards/ total liabilities
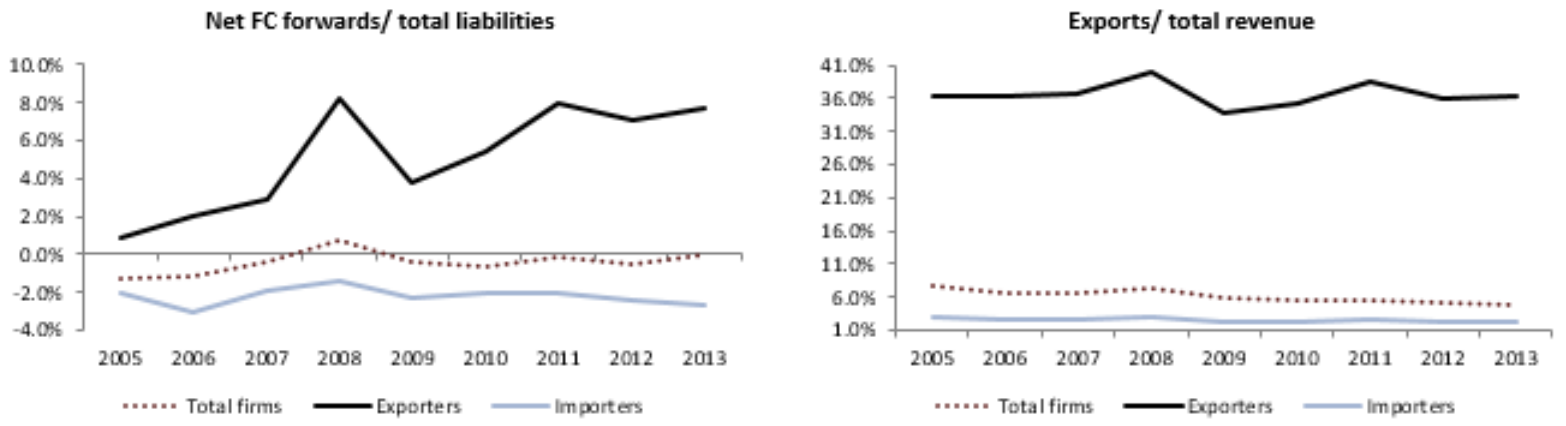

(Total FC debt-financial hedge)/ total assets

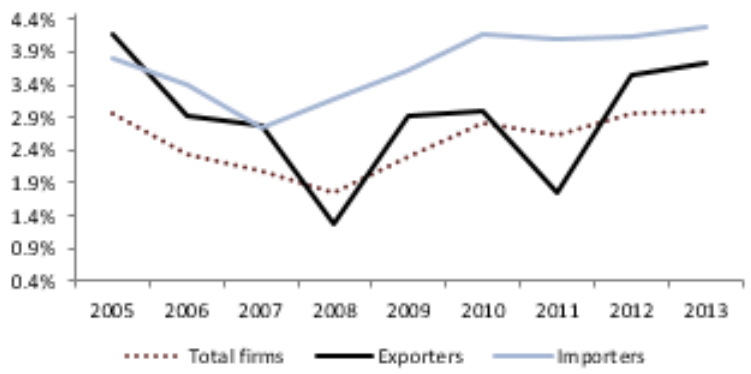

Source: Authors calculations based on SS, DIAN-DANE, SFC and BdR. 


\section{Annex C. Determinants of a Firm to Issue Debt in Foreign Currency (Marginal Effects after Probit)}

\begin{tabular}{|c|c|c|c|c|c|c|}
\hline & Probit & Probit & Probit & Probit & Probit & Probit \\
\hline VARIABLES & Total FC Debt & $\begin{array}{c}\text { Financial FC } \\
\text { Debt }\end{array}$ & FC Trade Credit & Total FC Debt & $\begin{array}{c}\text { Financial FC } \\
\text { Debt }\end{array}$ & FC Trade Credi \\
\hline \multirow[t]{2}{*}{ Assets } & $0.0590 * * *$ & $0.0378 * * *$ & $3.82 \mathrm{e}-07$ & $0.0596^{* * *}$ & $0.0381 * * *$ & $1.64 \mathrm{e}-06^{*}$ \\
\hline & $(0.00650)$ & $(0.00429)$ & $(2.55 \mathrm{e}-07)$ & $(0.00649)$ & $(0.00429)$ & $(9.48 \mathrm{e}-07)$ \\
\hline \multirow{2}{*}{$\begin{array}{l}\text { Assets owned } \\
\text { abroad }\end{array}$} & -0.00908 & -0.0126 & $1.37 \mathrm{e}-06$ & -0.0120 & -0.0134 & $6.06 \mathrm{e}-06$ \\
\hline & $(0.0602)$ & $(0.0365)$ & $(2.10 \mathrm{e}-06)$ & $(0.0634)$ & $(0.0387)$ & $(8.60 \mathrm{e}-06)$ \\
\hline \multirow[t]{2}{*}{ Leverage } & $0.301 * * *$ & $0.184 * * *$ & $2.52 \mathrm{e}-06$ & $0.305^{* * *} *$ & $0.188 * * *$ & $1.03 \mathrm{e}-05^{*}$ \\
\hline & $(0.0472)$ & $(0.0299)$ & $(1.73 \mathrm{e}-06)$ & $(0.0471)$ & $(0.0301)$ & $(6.25 \mathrm{e}-06)$ \\
\hline \multirow[t]{2}{*}{ Short term debt } & $0.0644 * * *$ & $0.0419 * * *$ & $4.45 \mathrm{e}-07$ & $0.0626^{* * *}$ & $0.0417 * * *$ & $1.33 \mathrm{e}-06$ \\
\hline & $(0.0141)$ & $(0.00894)$ & $(3.75 e-07)$ & $(0.0140)$ & $(0.00896)$ & $(1.22 \mathrm{e}-06)$ \\
\hline \multirow[t]{2}{*}{ Exports } & $0.312 * * *$ & $0.187 * * *$ & $1.94 \mathrm{e}-06$ & $0.308 * * *$ & $0.185^{* * *}$ & $7.48 \mathrm{e}-06^{*}$ \\
\hline & $(0.0407)$ & $(0.0256)$ & $(1.33 \mathrm{e}-06)$ & $(0.0401)$ & $(0.0254)$ & $(4.49 \mathrm{e}-06)$ \\
\hline \multirow[t]{2}{*}{ Imports } & 0.0354 & 0.0178 & $3.71 \mathrm{e}-07$ & 0.0350 & 0.0177 & $1.49 \mathrm{e}-06$ \\
\hline & $(0.0278)$ & $(0.0136)$ & $(3.84 \mathrm{e}-07)$ & $(0.0274)$ & $(0.0136)$ & $(1.44 \mathrm{e}-06)$ \\
\hline \multirow[t]{2}{*}{ Sales growth } & $-0.00563 * *$ & $-0.00269^{*}$ & $-1.36 e-07$ & $-0.00509 * *$ & -0.00220 & $-7.29 \mathrm{e}-07$ \\
\hline & $(0.00227)$ & (0.00139) & $(1.08 \mathrm{e}-07)$ & $(0.00223)$ & $(0.00136)$ & $(4.87 \mathrm{e}-07)$ \\
\hline \multirow{2}{*}{$\begin{array}{c}\text { Foreign } \\
\text { ownership }\end{array}$} & $0.0488^{* * *}$ & 0.00646 & $4.01 \mathrm{e}-06$ & $0.0557 * * *$ & $0.0101 * *$ & $1.62 \mathrm{e}-05^{*}$ \\
\hline & $(0.0111)$ & $(0.00468)$ & $(2.76 \mathrm{e}-06)$ & $(0.0114)$ & $(0.00488)$ & $(9.74 \mathrm{e}-06)$ \\
\hline \multirow[t]{2}{*}{ Spread } & & & & $0.0429 * * *$ & $0.0168^{*}$ & 7.47e-06* \\
\hline & & & & $(0.0158)$ & $(0.00952)$ & $(4.32 \mathrm{e}-06)$ \\
\hline \multirow{2}{*}{$\begin{array}{l}\text { Credit to private } \\
\text { sector }\end{array}$} & & & & $0.101 * * *$ & $0.124 * * *$ & $-1.96 \mathrm{e}-05^{*}$ \\
\hline & & & & $(0.0270)$ & $(0.0198)$ & $(1.12 \mathrm{e}-05)$ \\
\hline $\mathrm{RE}$ & YES & YES & YES & YES & YES & YES \\
\hline Time Effects & YES & YES & YES & NO & NO & NO \\
\hline $\begin{array}{l}\text { Number of } \\
\text { Observations }\end{array}$ & 34,064 & 34,064 & 34,064 & 34,064 & 34,064 & 34,064 \\
\hline Number of firms & 5,012 & 5,012 & 5,012 & 5,012 & 5,012 & 5,012 \\
\hline
\end{tabular}

Source: Authors calculations based on SS, DIAN-DANE, SFC and Banco de la República. Note: Standard Error in parenthesis $* * * \mathrm{p}<0.01,{ }^{*} \mathrm{p}<0.05,{ }^{*} \mathrm{p}<0.1$ 
Annex D. Hausman Test Results. Fixed Effects vs Random Effects

\begin{tabular}{|c|c|c|c|c|c|c|c|}
\hline & (1) & (2) & (3) & & (4) & $\left(5^{*}\right)$ & (6) \\
\hline & $\begin{array}{c}\text { Logit } \\
\text { Total FC } \\
\text { Debt }\end{array}$ & $\begin{array}{c}\text { Logit } \\
\text { Financial FC } \\
\text { Debt }\end{array}$ & $\begin{array}{c}\text { Logit FC } \\
\text { Trade } \\
\text { Debt }\end{array}$ & & $\begin{array}{c}\text { Logit } \\
\text { Total FC } \\
\text { Debt }\end{array}$ & $\begin{array}{c}\text { Logit } \\
\text { Financial FC } \\
\text { Debt }\end{array}$ & $\begin{array}{c}\text { Logit FC } \\
\text { Trade } \\
\text { Debt }\end{array}$ \\
\hline Chi2(15) & 487.87 & 335.86 & 59.83 & Chi2() & 169.19 & - & 11.29 \\
\hline $\mathrm{P}>\mathrm{Chi} 2$ & 0.0000 & 0.0000 & 0.0000 & $\mathrm{P}>\mathrm{Chi} 2$ & 0.0000 & - & 0.3355 \\
\hline
\end{tabular}

*Data fails to meet the asymptotic assumptions of the Hausman test.

Annex E. Determinants of Whether a Firm Issues Debt in Foreign Currency

(Marginal Effects after Logit, Fixed Effects)

\begin{tabular}{|c|c|c|c|c|c|c|}
\hline VARIABLES & $\begin{array}{c}(1) \\
\text { Logit } \\
\text { Total FC } \\
\text { Debt }\end{array}$ & $\begin{array}{c}(2) \\
\text { Logit } \\
\text { Financial FC } \\
\text { Debt }\end{array}$ & $\begin{array}{c}(3) \\
\text { Logit } \\
\text { FC Trade } \\
\text { Credit }\end{array}$ & $\begin{array}{c}\text { (4) } \\
\text { Logit } \\
\text { Total FC } \\
\text { Debt }\end{array}$ & $\begin{array}{c}(5) \\
\text { Logit } \\
\text { Financial FC } \\
\text { Debt }\end{array}$ & $\begin{array}{c}\text { (6) } \\
\text { Logit } \\
\text { FC Trade } \\
\text { Credit }\end{array}$ \\
\hline A, Assets & $\begin{array}{l}0.000296 * \\
(0.000156)\end{array}$ & $\begin{array}{l}0.000143 * \\
(8.19 \mathrm{e}-05)\end{array}$ & $\begin{array}{l}0.00635^{*} \\
(0.00383)\end{array}$ & $\begin{array}{c}0.000445^{* *} \\
(0.000225)\end{array}$ & $\begin{array}{l}6.47 \mathrm{e}-05^{*} \\
(3.55 \mathrm{e}-05)\end{array}$ & $\begin{array}{c}0.0860 \\
(0.0628)\end{array}$ \\
\hline I, Assets held abroad & $\begin{array}{l}-0.000186 \\
(0.000228)\end{array}$ & $\begin{array}{l}-0.000107 \\
(0.000111)\end{array}$ & $\begin{array}{c}0.0185 \\
(0.0354)\end{array}$ & $\begin{array}{l}-0.000306 \\
(0.000339)\end{array}$ & $\begin{array}{l}-4.99 \mathrm{e}-05 \\
(4.88 \mathrm{e}-05)\end{array}$ & $\begin{array}{c}0.269 \\
(0.363)\end{array}$ \\
\hline L, Leverage & $\begin{array}{l}0.000674 * \\
(0.000396)\end{array}$ & $\begin{array}{c}0.000259 \\
(0.000163)\end{array}$ & $\begin{array}{c}0.0236 \\
(0.0212)\end{array}$ & $\begin{array}{l}0.000995 * \\
(0.000556)\end{array}$ & $\begin{array}{l}0.000117 * \\
(7.00 \mathrm{e}-05)\end{array}$ & $\begin{array}{c}0.249 \\
(0.179)\end{array}$ \\
\hline $\mathrm{S}$, Short term debt & $\begin{array}{c}9.17 \mathrm{e}-05 \\
(5.90 \mathrm{e}-05)\end{array}$ & $\begin{array}{c}4.56 \mathrm{e}-05 \\
(2.96 \mathrm{e}-05)\end{array}$ & $\begin{array}{l}-0.00247 \\
(0.00592)\end{array}$ & $\begin{array}{c}0.000121 \\
(7.90 \mathrm{e}-05)\end{array}$ & $\begin{array}{c}2.00 \mathrm{e}-05 \\
(1.25 \mathrm{e}-05)\end{array}$ & $\begin{array}{l}-0.0712 \\
(0.0557)\end{array}$ \\
\hline Z, Exports & $\begin{array}{c}0.000403 \\
(0.000258)\end{array}$ & $\begin{array}{c}0.000158 \\
(0.000109)\end{array}$ & $\begin{array}{c}0.00537 \\
(0.00914)\end{array}$ & $\begin{array}{c}0.000538 \\
(0.000328)\end{array}$ & $\begin{array}{c}6.28 \mathrm{e}-05 \\
(4.15 \mathrm{e}-05)\end{array}$ & $\begin{array}{c}0.0105 \\
(0.0886)\end{array}$ \\
\hline IP, Imports & $\begin{array}{l}-2.63 e-05 \\
(3.03 e-05)\end{array}$ & $\begin{array}{c}-4.09 \mathrm{e}-06 \\
(1.07 \mathrm{e}-05)\end{array}$ & $\begin{array}{l}-0.00238 \\
(0.00318)\end{array}$ & $\begin{array}{l}-4.19 \mathrm{e}-05 \\
(4.58 \mathrm{e}-05)\end{array}$ & $\begin{array}{l}-1.70 \mathrm{e}-06 \\
(4.83 \mathrm{e}-06)\end{array}$ & $\begin{array}{l}-0.0385 \\
(0.0350)\end{array}$ \\
\hline G, Sales growth & $\begin{array}{l}-1.37 \mathrm{e}-05 \\
(1.32 \mathrm{e}-05)\end{array}$ & $\begin{array}{l}-3.98 \mathrm{e}-06 \\
(5.25 \mathrm{e}-06)\end{array}$ & $\begin{array}{l}-0.00118 \\
(0.00161)\end{array}$ & $\begin{array}{l}-1.50 \mathrm{e}-05 \\
(1.80 \mathrm{e}-05)\end{array}$ & $\begin{array}{l}-1.00 \mathrm{e}-06 \\
(2.20 \mathrm{e}-06)\end{array}$ & $\begin{array}{l}-0.0234 \\
(0.0190)\end{array}$ \\
\hline FO, Foreign ownership & $\begin{array}{c}8.36 \mathrm{e}-05 \\
(5.47 \mathrm{e}-05)\end{array}$ & $\begin{array}{c}2.21 \mathrm{e}-05 \\
(1.77 \mathrm{e}-05)\end{array}$ & $\begin{array}{c}0.00230 \\
(0.00340)\end{array}$ & $\begin{array}{l}0.000157 * \\
(9.45 \mathrm{e}-05)\end{array}$ & $\begin{array}{c}1.43 \mathrm{e}-05 \\
(9.82 \mathrm{e}-06)\end{array}$ & $\begin{array}{c}0.0388 \\
(0.0401)\end{array}$ \\
\hline s, Spread & & & & $\begin{array}{c}0.000289 \\
(0.000216)\end{array}$ & $\begin{array}{c}2.17 \mathrm{e}-05 \\
(2.11 \mathrm{e}-05)\end{array}$ & $\begin{array}{c}0.395^{* *} \\
(0.177)\end{array}$ \\
\hline $\mathrm{c}$, Credit to private sector & & & & $\begin{array}{c}0.000435 \\
(0.000303)\end{array}$ & $\begin{array}{c}0.000115 \\
(7.63 \mathrm{e}-05)\end{array}$ & $\begin{array}{l}-0.775^{*} \\
(0.405)\end{array}$ \\
\hline $\mathrm{FE}$ & YES & YES & YES & YES & YES & YES \\
\hline Time Effects & YES & YES & YES & NO & NO & NO \\
\hline Observations & 11,305 & 11,063 & 4,611 & 11,305 & 11,063 & 4,611 \\
\hline Number of firms & 1,578 & 1,545 & 635 & 1,578 & 1,545 & 635 \\
\hline
\end{tabular}

Source: Authors calculations based on SS, DIAN-DANE, SFC and Banco de la República. Note: Standard Error in parenthesis $* * * \mathrm{p}<0.01, * * \mathrm{p}<0.05, * \mathrm{p}<0.1$ 
Annex F. Panel A. Determinants of Whether a Firm Issues Debt in Foreign Currency (Marginal Effects after Logit, Pooled Data)

\begin{tabular}{|c|c|c|c|c|c|c|}
\hline VARIABLES & $\begin{array}{c}(1) \\
\text { Logit } \\
\text { Total FC Debt } \\
\end{array}$ & $\begin{array}{c}(2) \\
\text { Logit } \\
\text { Financial FC debt } \\
\end{array}$ & $\begin{array}{c}\text { (3) } \\
\text { Logit } \\
\text { FC Trade Credit } \\
\end{array}$ & $\begin{array}{c}(4) \\
\text { Logit } \\
\text { Total FC Debt }\end{array}$ & $\begin{array}{c}(5) \\
\text { Logit } \\
\text { Total FC Debt }\end{array}$ & $\begin{array}{c}(6) \\
\text { Logit } \\
\text { FC Trade Credit } \\
\end{array}$ \\
\hline A, Assets & $\begin{array}{c}0.0584 * * * \\
(0.00238)\end{array}$ & $\begin{array}{c}0.0634 * * * \\
(0.00210)\end{array}$ & $\begin{array}{c}0.00835^{* * * *} \\
(0.00117)\end{array}$ & $\begin{array}{c}0.0581 * * * \\
(0.00238)\end{array}$ & $\begin{array}{c}0.0633 * * * \\
(0.00210)\end{array}$ & $\begin{array}{c}0.00829 * * * \\
(0.00118)\end{array}$ \\
\hline $\begin{array}{l}\text { I, Assets held } \\
\text { abroad }\end{array}$ & $\begin{array}{l}0.235 \\
(0.274)\end{array}$ & $\begin{array}{l}0.225 \\
(0.258)\end{array}$ & $\begin{array}{c}0.0191 \\
(0.0579)\end{array}$ & $\begin{array}{c}0.241 \\
(0.277)\end{array}$ & $\begin{array}{l}0.235 \\
(0.260)\end{array}$ & $\begin{array}{c}0.0183 \\
(0.0584)\end{array}$ \\
\hline L, Leverage & $\begin{array}{c}0.867 * * * \\
(0.0342)\end{array}$ & $\begin{array}{c}0.789 * * * \\
(0.0306)\end{array}$ & $\begin{array}{c}0.155 * * * \\
(0.0143)\end{array}$ & $\begin{array}{l}0.867 * * * * \\
(0.0341)\end{array}$ & $\begin{array}{c}0.792 * * * \\
(0.0306)\end{array}$ & $\begin{array}{c}0.157 * * * \\
(0.0144)\end{array}$ \\
\hline S, Short term debt & $\begin{array}{c}0.150 * * * \\
(0.0134)\end{array}$ & $\begin{array}{c}0.170 * * * * \\
(0.0126)\end{array}$ & $\begin{array}{c}0.00602 \\
(0.00692)\end{array}$ & $\begin{array}{c}0.148 * * * \\
(0.0133)\end{array}$ & $\begin{array}{c}0.169 * * * \\
(0.0126)\end{array}$ & $\begin{array}{c}0.00498 \\
(0.00697)\end{array}$ \\
\hline Z, Exports & $\begin{array}{c}0.584 * * * \\
(0.0198)\end{array}$ & $\begin{array}{l}0.511 * * * \\
(0.0162)\end{array}$ & $\begin{array}{c}0.0903 * * * \\
(0.00586)\end{array}$ & $\begin{array}{l}0.581 * * * \\
(0.0197)\end{array}$ & $\begin{array}{c}0.516 * * * \\
(0.0164)\end{array}$ & $\begin{array}{c}0.0898 * * * \\
(0.00590)\end{array}$ \\
\hline IP, Imports & $\begin{array}{c}0.543 * * * \\
(0.0235)\end{array}$ & $\begin{array}{c}0.322 * * * \\
(0.0206)\end{array}$ & $\begin{array}{l}0.184 * * * * \\
(0.0102)\end{array}$ & $\begin{array}{c}0.539 * * * \\
(0.0235)\end{array}$ & $\begin{array}{c}0.317 * * * \\
(0.0205)\end{array}$ & $\begin{array}{l}0.184 * * * \\
(0.0102)\end{array}$ \\
\hline G, Sales growth & $\begin{array}{c}-0.0293 * * * \\
(0.00455)\end{array}$ & $\begin{array}{c}-0.0215^{* * * *} \\
(0.00394)\end{array}$ & $\begin{array}{c}-0.0214 * * * \\
(0.00330)\end{array}$ & $\begin{array}{c}-0.0285^{* * *} \\
(0.00450)\end{array}$ & $\begin{array}{c}-0.0207 * * * \\
(0.00388)\end{array}$ & $\begin{array}{c}-0.0223 * * * \\
(0.00336)\end{array}$ \\
\hline $\begin{array}{l}\text { FO, Foreign } \\
\text { ownership }\end{array}$ & $\begin{array}{l}0.0233 * * * \\
(0.00675)\end{array}$ & $\begin{array}{c}-0.0376^{* * * *} \\
(0.00581)\end{array}$ & $\begin{array}{l}0.0699 * * * \\
(0.00443)\end{array}$ & $\begin{array}{l}0.0259 * * * \\
(0.00671)\end{array}$ & $\begin{array}{c}-0.0350 * * * \\
(0.00581)\end{array}$ & $\begin{array}{l}0.0716^{* * * *} \\
(0.00444)\end{array}$ \\
\hline s, Spread & & & & $\begin{array}{c}0.0200 \\
(0.0337)\end{array}$ & $\begin{array}{c}0.0223 \\
(0.0308)\end{array}$ & $\begin{array}{c}0.0213 \\
(0.0169)\end{array}$ \\
\hline $\begin{array}{l}\mathrm{c}, \text { Credit to private } \\
\text { sector }\end{array}$ & & & & $\begin{array}{l}0.146^{* * * *} \\
(0.0337)\end{array}$ & $\begin{array}{l}0.291 * * * * \\
(0.0307)\end{array}$ & $\begin{array}{c}-0.191 * * * \\
(0.0169)\end{array}$ \\
\hline $\mathrm{RE} / \mathrm{FE}$ & NO & $\mathrm{NO}$ & $\mathrm{NO}$ & $\mathrm{NO}$ & NO & NO \\
\hline $\begin{array}{l}\text { Time Effects } \\
\text { Number of } \\
\text { Observations }\end{array}$ & $\begin{array}{c}\text { YES } \\
34,064\end{array}$ & $\begin{array}{c}\text { YES } \\
34,064\end{array}$ & $\begin{array}{c}\text { YES } \\
34,064\end{array}$ & $\begin{array}{c}\mathrm{NO} \\
34,064\end{array}$ & $\begin{array}{c}\mathrm{NO} \\
34,064\end{array}$ & $\begin{array}{c}\mathrm{NO} \\
34,064\end{array}$ \\
\hline
\end{tabular}

Source: Authors calculations based on SS, DIAN-DANE, SFC and Banco de la República.

Note: Robust Standard Error in parenthesis $* * * \mathrm{p}<0.01, * * \mathrm{p}<0.05,{ }^{*} \mathrm{p}<0.1$ 
Annex F. Panel B. Determinants of Whether a Firm Issues Debt in Foreign Currency (Marginal Effects after Probit, Pooled Data)

\begin{tabular}{|c|c|c|c|c|c|c|}
\hline VARIABLES & $\begin{array}{c}\text { (1) } \\
\text { Probit } \\
\text { Total FC Debt }\end{array}$ & $\begin{array}{c}(2) \\
\text { Probit } \\
\text { Financial FC debt }\end{array}$ & $\begin{array}{c}(3) \\
\text { Probit } \\
\text { FC Trade Credit }\end{array}$ & $\begin{array}{c}(4) \\
\text { Probit } \\
\text { Total FC Debt }\end{array}$ & $\begin{array}{c}(5) \\
\text { Probit } \\
\text { Total FC Debt } \\
\end{array}$ & $\begin{array}{c}(6) \\
\text { Probit } \\
\text { FC Trade Credit } \\
\end{array}$ \\
\hline A, Assets & $\begin{array}{l}0.0573 * * * \\
(0.00239)\end{array}$ & $\begin{array}{c}0.0638 * * * \\
(0.00218)\end{array}$ & $\begin{array}{l}0.0100^{* * * *} \\
(0.00129)\end{array}$ & $\begin{array}{l}0.0571 * * * \\
(0.00239)\end{array}$ & $\begin{array}{c}0.0635^{* * * *} \\
(0.00218)\end{array}$ & $\begin{array}{l}0.0101 * * * \\
(0.00129)\end{array}$ \\
\hline $\begin{array}{l}\text { I, Assets held } \\
\text { abroad }\end{array}$ & $\begin{array}{l}0.201 \\
(0.200)\end{array}$ & $\begin{array}{l}0.175 \\
(0.192)\end{array}$ & $\begin{array}{l}0.0257 \\
(0.0633)\end{array}$ & $\begin{array}{l}0.200 \\
(0.203)\end{array}$ & $\begin{array}{l}0.176 \\
(0.196)\end{array}$ & $\begin{array}{l}0.0242 \\
(0.0641)\end{array}$ \\
\hline L, Leverage & $\begin{array}{l}0.803 * * * \\
(0.0477)\end{array}$ & $\begin{array}{c}0.749 * * * \\
(0.0429)\end{array}$ & $\begin{array}{l}0.171 * * * \\
(0.0159)\end{array}$ & $\begin{array}{c}0.804 * * * \\
(0.0475)\end{array}$ & $\begin{array}{l}0.750^{* * * *} \\
(0.0427)\end{array}$ & $\begin{array}{c}0.173 * * * \\
(0.0160)\end{array}$ \\
\hline S, Short term debt & $\begin{array}{l}0.152^{* * * *} \\
(0.0153)\end{array}$ & $\begin{array}{l}0.165^{* * * *} \\
(0.0143)\end{array}$ & $\begin{array}{l}0.0158 * * \\
(0.00760)\end{array}$ & $\begin{array}{l}0.150^{* * * *} \\
(0.0152)\end{array}$ & $\begin{array}{l}0.164 * * * \\
(0.0143)\end{array}$ & $\begin{array}{l}0.0161 * * \\
(0.00761)\end{array}$ \\
\hline Z, Exports & $\begin{array}{l}0.571 * * * \\
(0.0186)\end{array}$ & $\begin{array}{l}0.521 * * * \\
(0.0161)\end{array}$ & $\begin{array}{l}0.106 * * * \\
(0.00708)\end{array}$ & $\begin{array}{l}0.569 * * * \\
(0.0186)\end{array}$ & $\begin{array}{l}0.519 * * * \\
(0.0160)\end{array}$ & $\begin{array}{l}0.105 * * * \\
(0.00714)\end{array}$ \\
\hline IP, Imports & $\begin{array}{l}0.428 * * * * \\
(0.0370)\end{array}$ & $\begin{array}{l}0.256 * * * * \\
(0.0316)\end{array}$ & $\begin{array}{c}0.178 * * * \\
(0.0173)\end{array}$ & $\begin{array}{l}0.426 * * * \\
(0.0369)\end{array}$ & $\begin{array}{l}0.254^{* * * *} \\
(0.0315)\end{array}$ & $\begin{array}{l}0.169 * * * \\
(0.0174)\end{array}$ \\
\hline $\mathrm{G}$, Sales growth & $\begin{array}{c}-0.0261 * * * \\
(0.00416)\end{array}$ & $\begin{array}{c}-0.0198 * * * \\
(0.00385)\end{array}$ & $\begin{array}{c}-0.0177 * * * \\
(0.00292)\end{array}$ & $\begin{array}{c}-0.0255^{* * * *} \\
(0.00411)\end{array}$ & $\begin{array}{c}-0.0189 * * * \\
(0.00378)\end{array}$ & $\begin{array}{c}-0.0180 * * * \\
(0.00291)\end{array}$ \\
\hline $\begin{array}{l}\text { FO, Foreign } \\
\text { ownership }\end{array}$ & $\begin{array}{l}0.0359 * * * \\
(0.00713)\end{array}$ & $\begin{array}{c}-0.0279 * * * \\
(0.00621)\end{array}$ & $\begin{array}{l}0.0787 * * * \\
(0.00486)\end{array}$ & $\begin{array}{l}0.0380 * * * \\
(0.00710)\end{array}$ & $\begin{array}{c}-0.0258 * * * \\
(0.00619)\end{array}$ & $\begin{array}{l}0.0805^{* * * *} \\
(0.00486)\end{array}$ \\
\hline s, Spread & & & & $\begin{array}{c}0.0289 \\
(0.0331)\end{array}$ & $\begin{array}{c}0.0260 \\
(0.0308)\end{array}$ & $\begin{array}{c}0.0285 \\
(0.0185)\end{array}$ \\
\hline $\begin{array}{l}\mathrm{c}, \text { Credit to } \\
\text { private sector }\end{array}$ & & & & $\begin{array}{l}0.150 * * * \\
(0.0329)\end{array}$ & $\begin{array}{l}0.291 * * * \\
(0.0305)\end{array}$ & $\begin{array}{c}-0.189 * * * \\
(0.0184)\end{array}$ \\
\hline $\begin{array}{c}\text { RE/FE } \\
\text { Time Effects }\end{array}$ & $\begin{array}{l}\text { NO } \\
\text { YES }\end{array}$ & $\begin{array}{l}\text { NO } \\
\text { YES }\end{array}$ & $\begin{array}{l}\text { NO } \\
\text { YES }\end{array}$ & $\begin{array}{l}\text { NO } \\
\text { NO }\end{array}$ & $\begin{array}{l}\text { NO } \\
\text { NO }\end{array}$ & $\begin{array}{l}\text { NO } \\
\text { NO }\end{array}$ \\
\hline $\begin{array}{l}\text { Number of } \\
\text { Observations }\end{array}$ & 34,064 & 34,064 & 34,064 & 34,064 & 34,064 & 34,064 \\
\hline
\end{tabular}

Source: Authors calculations based on SS, DIAN-DANE, SFC and Banco de la República. Note: Robust Standard Error in parenthesis ***p $<0.01, * * \mathrm{p}<0.05,{ }^{*} \mathrm{p}<0.1$ 


\section{Annex G. Instruments, Arellano-Bond and Sargan Tests}

Table G.1. Instruments used

\section{Specification 1}

Instruments for differenced equation

GMM-type: $L(2 / 3)$.investment $L(1 / 2)$.L2.FC Debt*loge

L(2/3).L2.FC Debt L(2/3).L2.Total liabilities

$\mathrm{L}(2 / 3)$.L2.Cash flow

Standard: D.yr2007 D.yr2008 D.yr2009 D.yr2010 D.yr2011 D.yr2012

Instruments for level equation

GMM-type: LD.investment L2D.FC Debt*loge L3D.FC Debt

L3D.Total liabilities L3D.Cash flow

Standard:_cons

\section{Specification 2}

Instruments for differenced equation

GMM-type: $L(2 / 3)$.investment L(1/2).L2.FC Debt*loge

$L(1 / 2)$.L2.FC Assets*loge L(2/3).L2.FC Debt

$L(2 / 3)$.L2.Total liabilities $L(2 / 3)$.L2.FC Assets

$\mathrm{L}(2 / 3)$.L2.Cash flow

Standard: D.yr2007 D.yr2008 D.yr2009 D.yr2010 D.yr2011 D.yr2012

Instruments for level equation

GMM-type: LD.investment L2D.FC Debt*loge

L2D.FC Assets*loge L3D.FC Debt L3D.Total liabilities

L3D.FC Assets L3D.Cash flow

Standard:_cons

\section{Specification 3}

Instruments for differenced equation

GMM-type: $L(2 / 3)$.investment $L(1 / 2)$.L2.FC Debt*loge

L(1/2).L2.FC Assets*loge L(1/2).L2.Net exports*loge

$L(2 / 3)$.L2.FC Debt L(2/3).L2.Total liabilities

$L(2 / 3)$.L2.FC Assets L(2/3).L2.Net exports

$\mathrm{L}(2 / 3)$.L2.Cash flow

Standard: D.yr2007 D.yr2008 D.yr2009 D.yr2010 D.yr2011 D.yr2012

Instruments for level equation

GMM-type: LD.investment L2D.FC Debt*loge 
L2D.FC Assets*loge L2D. Net exports*loge

L3D.FC Debt L3D.Total liabilities L3D.FC Assets

L3D.Net exports L3D.Cash flow

Standard:_cons

\section{Specification 4}

Instruments for differenced equation

GMM-type: $L(2 / 3)$.investment $L(1 / 2)$.L2.FC Debt*loge

L(1/2).L2.FC Assets*loge L(1/2).L2.Net exports*loge

$L(1 / 2)$.L2.Net Fwds*loge L(2/3).L2.FC Debt

$\mathrm{L}(2 / 3)$.L2.Total liabilities L(2/3).L2.FC Assets

$L(2 / 3)$.L2. Net exports $L(2 / 3)$.L2.Cash flow

$L(2 / 3)$.L2.Net Fwds

Standard: D.yr2007 D.yr2008 D.yr2009 D.yr2010 D.yr2011 D.yr2012

Instruments for level equation

GMM-type: LD.investment L2D.FC Debt*loge

L2D.FC Assets*loge L2D.Net exports*loge

L2D.Net Fwds*loge L3D.FC Debt L3D.Total liabilities

L3D.FC Assets L3D. Net exports L3D.Cash flow

L3D.Net Fwds

Standard:_cons

\section{Specification 5}

Instruments for differenced equation

GMM-type: $L(2 / 3)$.investment $L(1 / 2)$.L2.Balance-sheet exposure*loge

$L(1 / 2)$.L2.Net exports*loge $L(2 / 3)$.L2.Balance-sheet exposure

$\mathrm{L}(2 / 3)$.L2.Total liabilities $\mathrm{L}(2 / 3)$. L2. Net exports

$\mathrm{L}(2 / 3)$.L2.Cash flow

Standard: D.yr2007 D.yr2008 D.yr2009 D.yr2010 D.yr2011 D.yr2012

Instruments for level equation

GMM-type: LD.investment L2D.Balance-sheet exposure*loge

L2D.Net exports*loge L3D.Balance-sheet exposure L3D.Total liabilities

L3D.Net exports L3D.Cash flow

Standard:_cons 
Table G.1. Arellano-Bond Test for Zero Autocorrelation of the First Difference of the Error Term

\begin{tabular}{|c|c|c|}
\hline Order & $z$ & Prob $>z$ \\
\hline \multicolumn{3}{|c|}{ Specification 1} \\
\hline 1 & -10.147 & 0 \\
\hline 2 & -0.76738 & 0.4429 \\
\hline \multicolumn{3}{|c|}{ Specification 2} \\
\hline 1 & -10.24 & 0 \\
\hline 2 & -0.73656 & 0.4614 \\
\hline \multicolumn{3}{|c|}{ Specification 3} \\
\hline 1 & -10.75 & 0 \\
\hline 2 & -0.53506 & 0.5926 \\
\hline \multicolumn{3}{|c|}{ Specification 4} \\
\hline 1 & -10.202 & 0 \\
\hline 2 & -0.54283 & 0.5872 \\
\hline \multicolumn{3}{|c|}{ Specification 5} \\
\hline 1 & -10.127 & 0 \\
\hline 2 & -0.36821 & 0.7127 \\
\hline
\end{tabular}

The null hypothesis that $\operatorname{Cov}\left(\Delta \varepsilon_{i t}, \Delta \varepsilon_{i, t-k}\right)=0$ for $k=1,2$ is rejected at the 0.05 level if $p<$ 0.05 . If $\varepsilon_{i t}$ is serially uncorrelated, we would expect to reject at order 1 but not at higher orders. We reject at order 1 because $p=0.0000$. At order $2, \Delta \varepsilon_{i t}$ and $\Delta \varepsilon_{i, t-2}$ are not serially correlated because $p>0.1$.

Table G.2. Sargan Test for Over-Identification of Restrictions

STATA's estat sargan command implements this test, which cannot run if the model has been estimated with robust standard errors since errors $\varepsilon_{i t}$ must be i.i.d. It is therefore required to run the test without the option of error term robustness.

Null Hypothesis: overidentifying restrictions are valid

\begin{tabular}{|c|c|c|}
\hline Specification 1 & Specification 2 & Specification 3 \\
\hline $\operatorname{chi} 2(47)=47.4589$ & $=58.61414$ & $=70.70457$ \\
\hline Prob $>$ chi $2=0.4538$ & Prob $>$ chi $2=0.6667$ & Prob $>$ chi $2=0.7861$ \\
\hline Specification 4 & Specification 5 & \\
\hline $\operatorname{chi} 2(96)=83.05806$ & $=62.64853$ & \\
\hline Prob $>$ chi $2=0.8241$ & Prob $>$ chi $2=0.5244$ & \\
\hline
\end{tabular}


Annex H. Fixed Capital Investment and Foreign Currency Exposure with Unbalanced Panel Data Base.

\begin{tabular}{|c|c|c|c|c|c|}
\hline VARIABLES & (1) & (2) & (3) & (4) & (5) \\
\hline Lagged investment & $\begin{array}{l}-0.0000082^{* * *} \\
(1.29 \mathrm{e}-06)\end{array}$ & $\begin{array}{l}0.00039 * * * \\
(0.00004)\end{array}$ & $\begin{array}{l}0.00035^{* * *} \\
(0.000097)\end{array}$ & $\begin{array}{l}0.0047^{* * *} \\
(0.00009)\end{array}$ & $\begin{array}{l}0.000066 \\
(0.00006)\end{array}$ \\
\hline Lagged FC debt*loge & $\begin{array}{l}-0.0211 \\
(0.022)\end{array}$ & $\begin{array}{l}-0.0267 \\
(0.0208)\end{array}$ & $\begin{array}{l}-0.00929 \\
(0.02002)\end{array}$ & $\begin{array}{l}-0.00494 \\
(0.01914)\end{array}$ & \\
\hline Lagged FC assets*loge & & $\begin{array}{l}0.0989 * * * \\
(.01092)\end{array}$ & $\begin{array}{l}0.09051 * * * \\
(0.018152)\end{array}$ & $\begin{array}{l}0.0941^{* * *} \\
(0.0178)\end{array}$ & \\
\hline Lagged Net exports*loge & & & $\begin{array}{l}0.00065 \\
(0.00331)\end{array}$ & $\begin{array}{l}0.000678 \\
(0.00325)\end{array}$ & $\begin{array}{l}0.0029 \\
(0.00231)\end{array}$ \\
\hline Lagged Net Fwds*loge & & & & $\begin{array}{l}0.00751 \\
(0.01502)\end{array}$ & \\
\hline Lagged balance-sheet exposure*loge & & & & & $\begin{array}{l}-0.02382^{* *} \\
(0.01073)\end{array}$ \\
\hline FC debt & $\begin{array}{l}-0.0345^{* * *} \\
(0.0106)\end{array}$ & $\begin{array}{l}-0.0394 * * * \\
(0.01078)\end{array}$ & $\begin{array}{l}-0.03194 * * * \\
(0.00874)\end{array}$ & $\begin{array}{l}-0.03256^{* * *} \\
(0.00791)\end{array}$ & \\
\hline FC assets & & $\begin{array}{l}-0.0284^{* * *} \\
(0.01483)\end{array}$ & $\begin{array}{l}-0.03217^{* *} \\
(0.01542)\end{array}$ & $\begin{array}{l}-0.03265^{* *} \\
(0.01524)\end{array}$ & \\
\hline Balance-sheet exposure & & & & & $\begin{array}{l}-0.01755^{* * *} \\
(0.00629)\end{array}$ \\
\hline Net exports & & & $\begin{array}{l}-0.00008 \\
(0.00052)\end{array}$ & $\begin{array}{l}0.00014 \\
(0.00054)\end{array}$ & $\begin{array}{l}-0.000012 \\
(0.00041)\end{array}$ \\
\hline Total liabilities & $\begin{array}{l}0.0393^{* * *} \\
(0.0069)\end{array}$ & $\begin{array}{l}0.0434^{* * *} \\
(0.0085)\end{array}$ & & $\begin{array}{l}0.0333 * * * \\
(0.00530)\end{array}$ & $\begin{array}{l}0.02691 \\
(0.0056)\end{array}$ \\
\hline Net Fwds & & & & & \\
\hline Cash flow & $\begin{array}{l}0.0509 * * * \\
(0.0085)\end{array}$ & $\begin{array}{l}0.0706^{* * *} \\
(.01280)\end{array}$ & $\begin{array}{l}0.05057^{* * *} \\
(0.00782)\end{array}$ & $\begin{array}{l}0.04674 * * * \\
(0.0073)\end{array}$ & $\begin{array}{l}0.03441^{* * *} \\
(0.00729)\end{array}$ \\
\hline Constant & $\begin{array}{l}-0.0018 \\
(0.0049)\end{array}$ & $\begin{array}{l}-0.0062 \\
(0.0058)\end{array}$ & $\begin{array}{l}-0.00069 \\
(0.00410)\end{array}$ & $\begin{array}{l}0.00084 \\
(0.00381)\end{array}$ & $\begin{array}{l}0.00549 \\
(0.00408)\end{array}$ \\
\hline Observations & 31,770 & 31,770 & 31,770 & 31,770 & 31,770 \\
\hline Number of firms & 7,125 & 7,125 & 7,125 & 7,125 & 7,125 \\
\hline
\end{tabular}

Source: Author's calculations based on SS, SFC, DIAN-DANE and BdR.

Note: The dependent variable is the change in the stock of fixed capital in millions of COP adjusted by the CPI. All variables (except dummies) are scaled by previous period total assets. The real exchange rate is the nominal COP/USD exchange rate divided by domestic CPI. Net forward position corresponds to the difference in nominal values of long and short positions with local banks. Standard errors in parentheses. $* * * \mathrm{p}<0.01, * * \mathrm{p}<0.05, * \mathrm{p}<0.1$ 
Annex I. Determinants for the Use of Forward Exchange Derivatives by Firms (Marginal Effects after Probit)

\begin{tabular}{|c|c|c|c|c|c|c|}
\hline VARIABLES & $\begin{array}{c}\text { Probit } \\
\text { Long or short } \\
\text { positions }\end{array}$ & $\begin{array}{c}\text { Probit } \\
\text { Long or short } \\
\text { positions }\end{array}$ & $\begin{array}{c}\text { Probit } \\
\text { Long position }\end{array}$ & $\begin{array}{c}\text { Probit } \\
\text { Long position }\end{array}$ & $\begin{array}{c}\text { Probit } \\
\text { Short position }\end{array}$ & $\begin{array}{c}\text { Probit } \\
\text { Short position }\end{array}$ \\
\hline Assets & $\begin{array}{c}0.00732 * * * \\
(0.000913)\end{array}$ & $\begin{array}{c}0.00737 * * * \\
(0.000914)\end{array}$ & $\begin{array}{c}0.000116 * * * \\
(4.26 \mathrm{e}-05)\end{array}$ & $\begin{array}{c}0.000116^{* * *} * \\
(4.52 \mathrm{e}-05)\end{array}$ & $\begin{array}{c}0.00451^{* * * *} \\
(0.000643)\end{array}$ & $\begin{array}{c}0.00456 * * * \\
(0.000647)\end{array}$ \\
\hline $\begin{array}{l}\text { Assets owned } \\
\text { abroad }\end{array}$ & $\begin{array}{l}-0.0185 \\
(0.0136)\end{array}$ & $\begin{array}{l}-0.0184 \\
(0.0134)\end{array}$ & -0.000249 & $(0.000241)$ & $(0.00838)$ & $\begin{array}{c}-0.0133 \\
(0.00870)\end{array}$ \\
\hline Leverage & $\begin{array}{c}0.0185 * * * \\
(0.00515)\end{array}$ & $\begin{array}{c}0.0185 * * * \\
(0.00515)\end{array}$ & $\begin{array}{c}3.93 \mathrm{e}-05 \\
(0.000101)\end{array}$ & $\begin{array}{c}3.65 \mathrm{e}-05 \\
(0.000101)\end{array}$ & $\begin{array}{c}0.0149 * * * \\
(0.00358)\end{array}$ & $\begin{array}{r}0.0150 * * * \\
(0.00358)\end{array}$ \\
\hline FC debt & $\begin{array}{c}0.0596 * * * \\
(0.00740)\end{array}$ & $\begin{array}{r}0.0595 * * * \\
(0.00740)\end{array}$ & $\begin{array}{c}0.000379 * * \\
(0.000159)\end{array}$ & $\begin{array}{c}0.000380^{* * *} \\
(0.000159)\end{array}$ & $\begin{array}{r}0.0403 * * * \\
(0.00592)\end{array}$ & $\begin{array}{r}0.0402 * * * \\
(0.00589)\end{array}$ \\
\hline $\begin{array}{l}\text { Short term } \\
\text { debt }\end{array}$ & $\begin{array}{l}0.0184 * * * \\
(0.00303)\end{array}$ & $\begin{array}{l}0.0182 * * * \\
(0.00301)\end{array}$ & $\begin{array}{l}3.72 \mathrm{e}-05 \\
(4.87 \mathrm{e}-05)\end{array}$ & $\begin{array}{l}3.71 \mathrm{e}-05 \\
(4.89 \mathrm{e}-05)\end{array}$ & $\begin{array}{l}0.0144 * * * \\
(0.00241)\end{array}$ & $\begin{array}{l}0.0143 * * * \\
(0.00239)\end{array}$ \\
\hline Exports & $\begin{array}{c}0.0247 * * * \\
(0.00403)\end{array}$ & $\begin{array}{r}0.0243 * * * \\
(0.00400)\end{array}$ & $\begin{array}{c}0.000931 * * * \\
(0.000352)\end{array}$ & $\begin{array}{c}0.000941 * * * \\
(0.000356)\end{array}$ & $\begin{array}{c}-0.00367 * \\
(0.00215)\end{array}$ & $\begin{array}{c}-0.00399 * \\
(0.00215)\end{array}$ \\
\hline Imports & $\begin{array}{c}0.00951 * * \\
(0.00437)\end{array}$ & $\begin{array}{r}0.00939 * * \\
(0.00433)\end{array}$ & $\begin{array}{l}-1.02 \mathrm{e}-05 \\
(3.98 \mathrm{e}-05)\end{array}$ & $\begin{array}{l}-8.22 \mathrm{e}-06 \\
(3.96 \mathrm{e}-05)\end{array}$ & $\begin{array}{l}0.00700 * \\
(0.00365)\end{array}$ & $\begin{array}{l}0.00689 * \\
(0.00360)\end{array}$ \\
\hline Sales growth & $\begin{array}{c}-0.00171 * * * \\
(0.000558)\end{array}$ & $\begin{array}{c}-0.00172 * * * \\
(0.000556)\end{array}$ & $\begin{array}{l}-7.60 \mathrm{e}-06 \\
(1.21 \mathrm{e}-05)\end{array}$ & $\begin{array}{l}-6.99 \mathrm{e}-06 \\
(1.21 \mathrm{e}-05)\end{array}$ & $\begin{array}{c}-0.00106 * * * \\
(0.000369)\end{array}$ & $\begin{array}{c}-0.00108 * * * \\
(0.000369)\end{array}$ \\
\hline Foreign & -0.00168 & -0.00143 & $7.36 \mathrm{e}-05$ & $7.37 \mathrm{e}-05$ & $-0.00225 * * *$ & $-0.00208 * * *$ \\
\hline Interest rate & (0.00109) & $\begin{array}{r}(0.00109) \\
-0.139 * * *\end{array}$ & $(4.62 \mathrm{e}-05)$ & $\begin{array}{l}(4.58 \mathrm{e}-05) \\
-0.000176\end{array}$ & $(0.000691)$ & $\begin{array}{r}(0.000688) \\
-0.0851 * * *\end{array}$ \\
\hline Forward & & $\begin{array}{c}(0.0258) \\
-0.000953\end{array}$ & & $\begin{array}{c}(0.000544) \\
-0.000453^{*}\end{array}$ & & $\begin{array}{r}(0.0178) \\
-0.00676\end{array}$ \\
\hline Premium & & $(0.00645)$ & & $(0.000238)$ & & $(0.00435)$ \\
\hline $\begin{array}{l}\text { Exchange rate } \\
\text { CB Purchases }\end{array}$ & & $\begin{array}{c}-2.69 \mathrm{e}-06 \\
(7.08 \mathrm{e}-06) \\
-1.40 \mathrm{e}-06 * * *\end{array}$ & & $\begin{array}{c}4.27 \mathrm{e}-07 * \\
(2.35 \mathrm{e}-07) \\
3.18 \mathrm{e}-09\end{array}$ & & $\begin{array}{c}-1.51 \mathrm{e}-06 \\
(4.62 \mathrm{e}-06) \\
-9.76 \mathrm{e}-07 * * *\end{array}$ \\
\hline & & $(3.96 \mathrm{e}-07)$ & & $(8.95 \mathrm{e}-09)$ & & $(2.72 \mathrm{e}-07)$ \\
\hline CB Sales & & $\begin{array}{c}-1.29 \mathrm{e}-05^{* * *} \\
(4.00 \mathrm{e}-06)\end{array}$ & & $\begin{array}{c}-4.44 \mathrm{e}-07 * * \\
(1.85 \mathrm{e}-07)\end{array}$ & & $\begin{array}{c}-6.39 \mathrm{e}-06^{* *} \\
(2.62 \mathrm{e}-06)\end{array}$ \\
\hline $\mathrm{RE}$ & YES & YES & YES & YES & YES & YES \\
\hline Time Effects & YES & NO & YES & NO & YES & NO \\
\hline Observations & 34,064 & 34,064 & 34,064 & 34,064 & 34,064 & 34,064 \\
\hline $\begin{array}{l}\text { Number of } \\
\text { firms }\end{array}$ & 5,012 & 5,012 & 5,012 & 5,012 & 5,012 & 5,012 \\
\hline
\end{tabular}

Source: Authors calculations based on SS, DIAN-DANE, SFC and BdR. Note: Robust standard error in parenthesis. ${ }^{* * *} \mathrm{p}<0.01,{ }^{* *} \mathrm{p}<0.05,{ }^{*} \mathrm{p}<0.1$ 